\title{
Humanos en la mesa de los dioses: la escatológica fenicia y los frisos de Pozo Moro
}

\section{Humans on the Gods' Table: the Phoenician Eschatology and the Pozo Moro Friezes}

\author{
Fernando LóPEZ PARDO \\ Publicado por primera vez en A. GonzÁlez Prats (ed.), El mundo funerario. Actas \\ del III Seminario Internacional sobre Temas Fenicios. Guardamar del Segura, 3-5 \\ de mayo de 2002. Homenaje al Prof. D. Manuel Pellicer Catalán, Alicante, \\ 2004, 495-537
}

Es absolutamente cierto que sobre las concepciones de Ultratumba en el mundo fenicio-púnico es muy poco lo que sabemos, debido al laconismo de las inscripciones funerarias y a la escasez de datos alusivos al tema en autores griegos y latinos, totalmente insuficientes. ${ }^{1}$ Por su parte, a pesar de los recientes y minuciosos análisis contextuales de los registros funerarios, la falta precisamente del soporte de una documentación textual extensa dificulta y hace inseguro un acercamiento por esta vía. Es por otro lado evidente que las figuras y demás objetos depositados en las tumbas participan de la elipsis simbólica característica de la cultura fenicia que obliga al ejercicio casi imposible de conocer el prácticamente desaparecido fondo mítico/religioso que se esconde tras ellos.

La religión fenicio-púnica de la Edad del Hierro muestra una notable continuidad respecto a sus antecedentes de la Edad del Bronce, perceptible a través de la documentación ugarítica que nos ha provisto un corpus mítico y religioso excepcional, ${ }^{2}$ lo cual no obsta que se deban tomar y se tomen las reservas oportunas acerca de la fosilización o no de los elementos que permanecen después. El caso es que dicha documentación, cuando falta la correspondiente a la Edad del Hierro, nos ha servido para desvelar parcialmente el fondo escatológico fenicio de dos frisos pertenecientes al monumento funerario de Pozo Moro (en adelante P.M.) en Albacete. Los beneficios de retorno que reporta una lectura de estas características de las dos escenas del monumento pueden ser destacables al permitir aclararnos ciertos aspectos poco conocidos de la visión fenicia del Más Allá, pues al percibir las concomitancias en los extremos se puede asegurar su vigencia en el transmisor.

1 RIBICHINI 1991, 125.

2 Bonnet - Xella 1995, 317; Lipinski 1995, passim; Olmo Lete 1996, passim. 


\section{El friso del "banquete": cuestión de teorías (fig. 1)}

El primer relieve al que nos referimos ha sido considerado, no sin razón, el más complejo de todos y es, sin duda, el más "hermético", habiéndose dado de él las interpretaciones más variadas, tanto es así que no existe un acuerdo a la hora de denominarlo: "escena de banquete", "banquete infernal", "ritual de cocimiento", "escena monstruosa", "escena de sacrificio", ${ }^{3}$ "cannibalistic relief". ${ }^{4}$ Parece primar en todas ellas la consideración que de alguna manera se refiere al mundo infernal ibérico acrisolado a partir de un tema oriental original. Aunque a la hora de definir cual es dicho fondo y cual la adaptación indígena las propuestas han sido muy distintas. Así para Martín Almagro Gorbea la divinidad infernal representada sería asimilable a alguna de las deidades infernales de la mitología oriental, ya sea Moloch, Kumarbi-Kronos o Tártaro. ${ }^{5}$ Para José María Blázquez los personajes representados serían unos guardianes de la muerte: genios, daimones o dioses en un banquete de ultratumba, ${ }^{6} \mathrm{o}$ bien un mito oriental de carácter infernal quizás relacionado con sacrificios humanos infantiles. ${ }^{7}$ Recientemente lo ha considerado como una reelaboración del mito de Cronos devorando a sus hijos. ${ }^{8}$ Heider $^{9}$ lo considera una escena de canibalismo por parte de una deidad ctónica, escena que de alguna manera sería un calco de un sacrificio infantil practicado por los antiguos semitas. ${ }^{10}$ Hipótesis desaconsejada por Brown ${ }^{11}$ por la ausencia de cualquier documentación que relacione el canibalismo con los sacrificios del tophet, así como por el carácter mitológico de los demás relieves del monumento que al ser de carácter funerario excluye cualquier relación con dicho ritual. Se ha considerado también una escena cuyo modelo sería un banquete real o aristocrático, profusamente documentado en los palacios levantinos, aprovechado para una representación cultual con connotaciones de antropofagia. ${ }^{12}$ Todas ellas son las explicaciones que mejor tienen en cuenta el fondo cultural al que pertenecen la iconografía y el estilo del friso.

Quizás quien más se ha detenido en explicar el contenido de la escena es Ricardo Olmos, ${ }^{13}$ para quien la representación se refiere a dos momentos sucesivos que adaptarían el ancestral mito de mutación a la inmortalidad conocido como del "niño en el caldero". Una primera acción de cocimiento del humano descuartizado dentro del cuenco que está sobre el fuego, y una segunda, la ofrenda al dios entronizado del mismo cuenco con el hombre para ser deglutido, pero que posteriormente será sustituido por la ofrenda del jabalí sacrificado. Dicho acto de sustitución es lo que posibilita

\footnotetext{
3 Madrigal Belinchón 1995, 14; Castelo Ruano 1995, 63.

4 Brown 1991, 70.

5 Almagro Gorbea 1993-1994, 114.

6 BlázQuez 1979, 165.

7 BlázQuez 1999, 52.

8 BlÁzQuez 1998-1999, 115; ID. 2001, 205-206.

9 Heider 1985, 189-192, siguiendo a Ch. Kennedy en un trabajo inédito.

10 HeIDER 1985, 191.

11 BRown 1991, 72.

12 BLECH 1997, 202.

13 Olmos 1996, 107.
} 


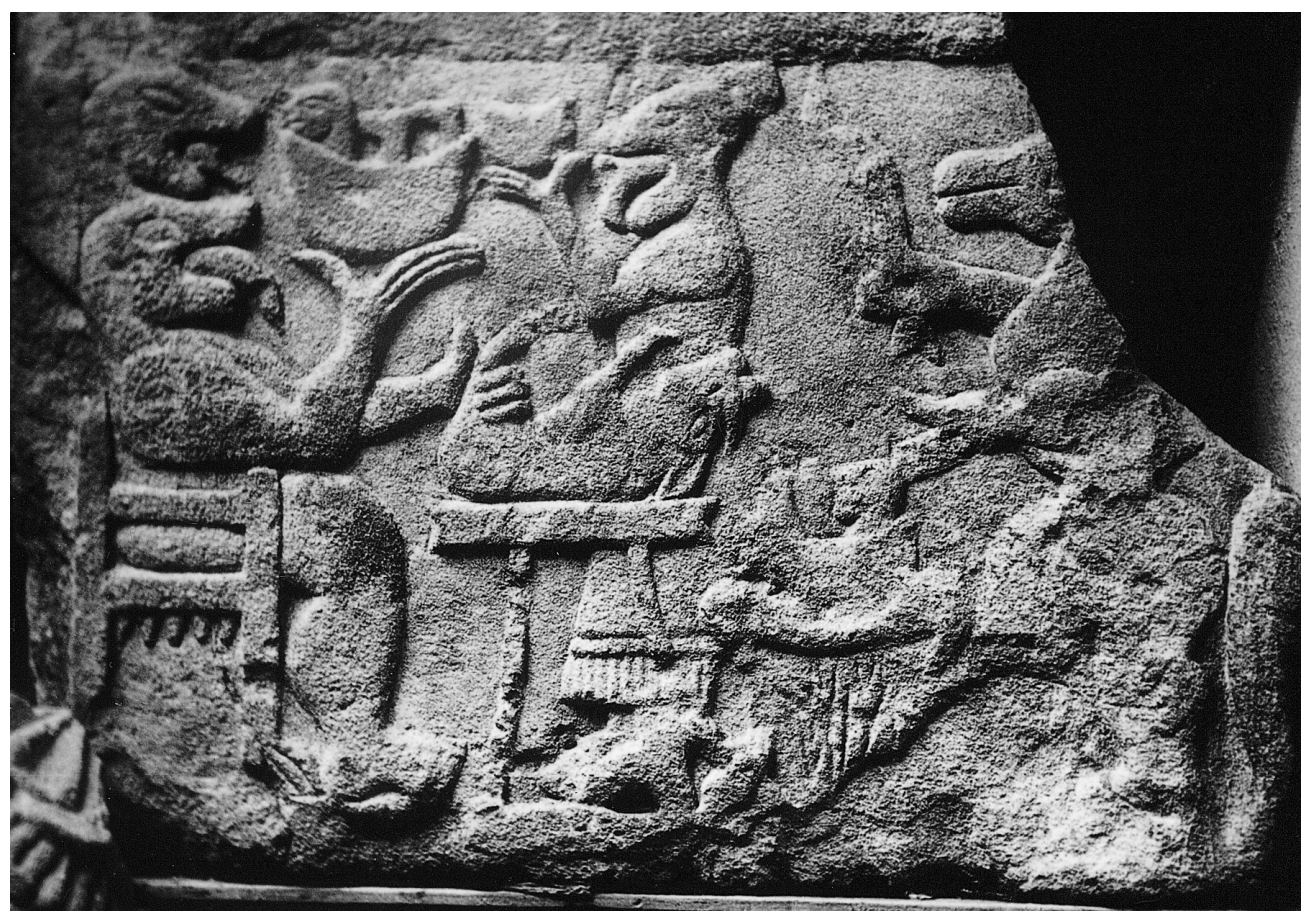

Fig. 1. Escena del "banquete” (según Almagro Gorbea, 1983).

que la cocción, que se aprecia como de inmortalidad para hacer viable su consumo por el dios, a la postre confiera el status inmortal al difunto que ha sido llevado a la mesa del dios. Continuando con la explicación anterior, J. M. Fernández Rodríguez ${ }^{14}$ considera, por el contrario, que sí hay comunión mística del hombre por la deidad, lo cual le conferiría la nueva condición heroica e inmortal.

A pesar de la disparidad de las hipótesis, más aparente que real, todas han puesto de relieve aspectos de interés y han ido perfilando y estrechando el cerco sobre el significado último del documento.

\section{Beber/establecer}

El personaje entronizado que vemos en primer plano sostiene un cuenco con un humano que aparece desmembrado, según se aprecia por la disposición de las piernas en relación con la cabeza, emergiendo ambas por el borde del vaso. Una situación semejante presenta el humano que se encuentra en otro cuenco colocado sobre un trípode. Tal representación tiene que ver con el tránsito mortuorio, a juzgar por cómo se nos describe en el ciclo de Baal, donde Mot, el dios de la muerte, cuyas fauces se

14 Fernández Rodríguez 1996, 303-304. 
abren entre la tierra y el cielo, pretende triturar con su boca a Baal. ${ }^{15}$ También en otro pasaje del mismo mito Baal aconseja a sus heraldos ponerse en guardia y no acercarse a Mot, no sea que haga de ellos "como un cordero en la boca, como un cabrito en las muelas de sus fauces". ${ }^{16}$ La misma tarea desempeñan en el ámbito babilónico Lugal-Erra y Meslamtaea, colocados a la entrada del Inframundo donde despedazan a los muertos. ${ }^{17}$

Parece pues evidente que se ha querido representar a sendos individuos exactamente tras dicho trance de la forma que la tradición cananea compendia el deceso.

Por otra parte, hemos de preguntarnos por la razón de que uno de los difuntos aparezca dentro de un cuenco que es ofrecido a la divinidad/es entronizada. No se trata, evidentemente, de la escenificación de dicho tránsito, abominable, por otra parte, para la iconografía levantina. Creo que volvemos a encontrar la explicación en las tabillas ugaríticas. En ellas de forma recurrente la bebida y la acción de beber corresponden al lexema šty. ${ }^{18}$ Sin embargo en KTU 1.108 la lectura contextual del documento impide admitir esta acepción de forma literal. En el texto se señala que el rey difunto ha sido "establecido" (bebido) Rapha, ha sido "establecido" (bebido) Gathar (el rey mítico de Ugarit convertido en primer rapha de la dinastía, al que se quiere asimilar el rey difunto), ${ }^{19}$ también en $K T U 1.113 .{ }^{20} \mathrm{El}$ difunto es sucesivamente bebido/establecido por diferentes divinidades entre las que se encuentran El, Anat, Baal, Eloah, Reshef, lo cual indica la aceptación por parte de todos ellos de la nueva condición divina del rey muerto. Sin embargo será a Baal al que pida el rey extinto su nueva condición de rapha "rey eternal" ${ }^{21}$ Creo que la escena representada está jugando con este doble significado de tal manera que la acción de la divinidad con la boca entreabierta que se acerca el cuenco con el humano desmembrado le está procurando la inmortalidad. Por otra parte, la acción de beber -y no de devorar- se encuentra perfectamente destacada en el friso con la doble acción del personaje divino, bebe la copa con el humano y come el jabalí situado sobre la mesa que coge con la otra mano. La permanencia de ambos significados en el mundo fenicio-púnico se encuentra plenamente acreditada en documentos epigráficos: $\check{s}-t-y$ "drink"; ${ }^{22} \check{s}-t$ "place", "set", "stipulate", "make", etc. ${ }^{23}$ Esa perduración asegura la vigencia inteligible de la escena representada en el friso en el ambiente cultural y religioso fenicio occidental.

$15 K T U 1.5$ I, $5-8$.

16 KTU 1.4 VIII 18-20; Xella 1984, 110.

17 Black - Green 1992, 123-124. En el conocido "Poema de Erra" éste es una divinidad relacionada con la destrucción, la guerra y las catástrofes que posibilita, tras el abandono momentáneo de Marduk de sus funciones benéficas, el ascenso desde el Apsu de los demonios y los terribles Anunnaki (Poema de Erra 147175; Trad. Jiménez Zamudio 1998, 61-62); sobre la interpretación en clave histórica del mito en relación con las invasiones arameas véase Liverani 1995, 599.

18 Ejem. KTU 1.6 IV 2/13; Xella 1981, 305; Olmo Lete 1992, n. 57; ID. 1998, 285, n. 1.

19 Olmo Lete 1998, 285, n. 3.

20 Olmo Lete 1992, 127.

$21 K T U$ 1.108, 17-28. Distintos reyes de Ugarit, difuntos y divinizados, son mencionados con el determinativo divino y reciben ofrendas (KTU, 1.113; 1.161; 1.22; RIBICHINI1981, 846).

22 poen. $1142(\mathrm{Pu})$. Krahmalkov 2000, 485.

23 KAI 26; KAI 69; KAI 24; KAI 43. KrahmaLKov 2000, 483-484. 
Un segundo conjunto perfectamente identificable se compone de un ser con la cabeza y cuerpo de hipopótamo (?), mejor que de equino, ${ }^{24}$ marcadamente distinto de los otros personajes del friso no sólo por su apariencia sino también por la diferente actitud que manifiesta: tiene la boca cerrada, destacándose así su no participación en el extraño convite, despejando cualquier duda sobre el papel que le ha tocado desempeñar; sostiene en su mano derecha un cuchillo y con la izquierda coloca sobre un trípode un cuenco o caldero del que sobresale el segundo humano desmembrado; bajo el trípode arde un fuego al que dirige su cabeza una serpiente que se arrastra por el suelo, elemento muy significativo que no ha tenido cabida en otras explicaciones de la escena. Como veremos a continuación es evidente que aquí nos encontramos con el mensaje opuesto al transmitido por el primer conjunto, frente al acto de exaltación a la condición de rapha de un individuo, la aniquilación o tormento de otro. El difunto ha sido excluido de la divinización y por lo tanto está siendo extinguido o atormentado y anulada su existencia ultraterrena beatífica.

Este tema de consunción no lo hemos podido rastrear explícitamente en la literatura cananea, sin embargo la pluralidad de elementos que componen este segundo conjunto es lo suficientemente generosa como para que otros patrones escatológicos antes no tenidos en cuenta sean los que consideramos que intervienen en este caso. A este propósito remito a la literatura funeraria egipcia referida a los tormentos dirigidos a anular la existencia en el ritual realizado en el "Lugar de aniquilación". Según recoge G. Scandone Matthiae, ${ }^{25}$ "En la hora undécima, el fuego colmaba profundas fosas custodiadas por genios armados de cuchillos y por una serpiente: en ellas se consumían perpetuamente cuerpos, almas, sombras y cabezas de los pecadores, al paso que el dios Horus les vociferaba: ¡Vuestros cuerpos deben ser sometidos a suplicio con el cuchillo que atormenta, vuestras almas aniquiladas, vuestras sombras holladas, vuestras cabezas mutiladas!". ${ }^{26}$ El ritual de exterminio se completaba por la acción de la serpiente que escupía fuego: “ ¡Lanza la antorcha en tu caldero, cuece a los enemigos de Osiris! ¡Oh vosotros dos Ureos, "Llama” y "Abrasador", disparad vuestra llama, encended vuestro fuego debajo de todo caldero que contiene a los enemigos de Osiris!". ${ }^{27}$

Sin duda el personaje con cabeza y figura de hipopótamo (? ${ }^{28}$ que sostiene un cuchillo que parece dirigir hacia el cuenco/caldero con el humano triturado es equiparable al genio armado con cuchillo que atormenta las almas y los cuerpos aniquilados en el Duat y, por su parte, la serpiente que abrasa el caldero que contiene a los enemi-

24 L. A. Ruiz Cabrero me ha llamado la atención sobre la posibilidad de que se trate de un hipopótamo. Efectivamente la larga ranura de la boca dificulta imaginar que se trate de un équido como habitualmente se ha sugerido a manera de hipótesis. También la extraordinaria pesadez de los cuartos traseros parecen más propios de este animal que de un caballo.

25 Scandone Matthiae 1991, 34.

26 Am Duat, 189, 1-7.

27 Libro de las Puertas, 97.

28 Algunas deidades egipcias tienen cuerpo de hipopótamo, entre ellas la más conocida es Tueris. No es de extrañar que el daimon que aniquila o atormenta al humano pueda tener este aspecto, dado que la agresividad del hipopótamo frente a otros animales, especialmente los cocodrilos, era conocida en el antiguo Egipto. Sin embargo no podemos identificar el animal representado con la "devoradora" misma, ya que aunque esta cuenta con cuartos traseros de hipopótamo, su cabeza es de cocodrilo y sus garras delanteras y melena son leoninas. 
gos de Osiris es en el relieve la serpiente que dirige su cabeza al fuego que arde bajo el recipiente con los restos humanos colocado sobre un trípode.

Efectivamente la literatura semítica occidental del segundo milenio nos ha privado de la documentación de este aspecto negativo del Más Allá en la práctica cultual, preocupada quizás sólo en la exaltación divina de los antepasados de la dinastía reinante, en razón de los ambientes palaciales y sacerdotales en los que han aparecido los textos. Sin embargo, su misma existencia pone de relieve su contrapunto, el de aquellos que no acceden a la condición refaítica. Algo que pone de relieve la inscripción del sarcófago de Eshmunazor, rey de Sidón, fechado en torno al 500 a.C., donde se niega a los profanadores de tumbas, ya sean reyes o plebeyos, la existencia ultramundana con la siguiente frase: "que no tengan reposo entre los rephaim". ${ }^{29}$ También en el texto disuasorio se aprecia, sin lugar a dudas, que es posible el acceso a esta condición no sólo a reyes y nobles, sino también a los demás mortales. En un epitafio bilingüe de El-Amrouni, en el sur de Túnez, del s. II d.C. ${ }^{30}$ los rephaim son equiparados a los dioses Manes ${ }^{31}$ y se califica de "divinos" a los rephaim, lo cual muestra la pervivencia de la vieja tradición siria de su consideración divinal, ${ }^{32}$ esta vez aplicada a los antepasados del difunto de El-Amrouni. No parece plausible, sin embargo, la idea de que los rephaim pasaron a designar a los muertos en general, sino más bien a todos aquellos que, aparentemente al margen de cualquier consideración social o de status, no han sido apartados de la vida ultraterrena.

El momento "crítico" representado en la escena de Pozo Moro era precedido por la trayectoria vital del humano que va a ser bebido/establecido rapha, en este caso de connotaciones heroicas, pero también la preparación del viaje al Más Allá en el que vemos de nuevo la influencia egipcia, lo que hace más pertinente la lectura aquí propuesta de la escena de consunción.

A este respecto es necesario traer a colación las láminas de metal y las que a buen seguro eran más numerosas de papiro y tejido que se guardaban en el sinfín de estuches hallados en las tumbas fenicias y púnicas, algunos hallados con restos de ellas irrecuperables. En las que se nos han conservado lo representado no es el juicio del alma, sino un tema colateral que inicialmente no tenía sentido propiamente escatológico. Las figuras de los rollos representan a los decanos, los dioses guardianes, forma humanizada de las constelaciones que representan a su vez la división de la noche en doce horas. ${ }^{33}$ Esta división del tiempo de carácter astral fue transferida en Egipto a su concepción escatológica ya que el cielo nocturno, por el que se desplaza la deidad solar, se equipara al mundo de los muertos. ${ }^{34} \mathrm{~A}$ pesar de la utilidad ctónica del porta-amuleto y del rollo que guarda, es muy posible que éste se portara en vida ya que seguramente se consideraba como una guía que era necesario tener consigo para

29 KAI 14; Fantar 1970, 17; BonNet 1996, 18; Olmo Lete 1996, 74.

30 KAI 117.

31 Fantar 1970, 17; Lipinski 1995, 190; Olmo Lete 1996, 77.

32 Ribichini 1991, 127-128; Grass - Rouillard - Teixidor 1991, 210.

33 VerCoutter 1945, 326. Los decanos ya aparecen representados en objetos egipcios del s. IX a.C., de la dinastía XXII, aunque la representación más completa la tenemos en el templo de Hathor en Dendera de época romana (VERCOUTTER 1945, 319).

34 MaAss-Lindemann - MaAss 1997, 275. 
el complicado viaje astral al Más Allá, donde tendrá lugar el juicio divino. La comprensión del significado de este tipo de documento por parte de los fenicios era plena, pues la idea de portar amuletos con estos rollos no es propiamente egipcia, ya que no han aparecido en las tierras del Nilo, sino que es genuinamente fenicia, y son por lo tanto realizados por artesanos semitas copiando papiros egipcios. ${ }^{35}$ Esa relación con el más allá es redundante en la lámina de Cagliari donde aparece representada una barca después del desfile de dioses y diosas, algunos de apariencia animal. ${ }^{36}$ Muy interesante a este respecto es la inscripción de la lámina de oro de Moraleda de Zafayona que ha leído L. A. Ruiz Cabrero, ${ }^{37}$ "proteja y guarde a NP, hijo de NP. Eshmun príncipe disuelva a hw por todo el tiempo /// el paladar de la devoradora" solicitándose pues el auxilio del dios sanador fenicio para evitar la extinción y acceder por lo tanto a la inmortalidad. ${ }^{38}$

\section{La escena del "jabalí bifronte"}

Unas hiladas más arriba del friso del "Banquete" se encontraba un relieve más corto, compuesto por un único bloque, conocido como la escena del "jabalí bifronte" 39 (fig. 2). El relieve representa a dos jabalíes unidos por el tronco, con cerdas erizadas y sujetos por dos seres cuya mitad inferior es serpentiforme y la superior humana, personajes con larga melena y nariz picuda (fig. 3). La sujeción del dúplice animal la realizan mediante sus cuerpos serpentiformes que se lían en las patas del mismo y con las manos que agarran la crin próxima a la cabeza. Se puede considerar el único friso que nos ha llegado completo. ${ }^{40} \mathrm{M}$. Almagro Gorbea ${ }^{41}$ interpreta la escena como un episodio mitológico de enfrentamiento entre fuerzas relacionadas con la muerte, al atribuir un carácter funerario al jabalí y ctónico a la serpiente. Otras interpretaciones abogan por una visión generativa del tema, así R. Olmos ve en el jabalí un ser engendrador que al hozar la tierra da lugar a un ser híbrido que va adquiriendo forma humana ${ }^{42}$ con lo cual abre la posibilidad de que no se trate realmente de una escena de lucha, que nosotros tampoco vemos. Fernández Rodríguez, ${ }^{43}$ por su parte y siguiendo parcialmente los planteamientos de Almagro Gorbea y Olmos, considera

5 MaAss-Lindemann - MaAss 1997, 288.

36 Vercoutter 1945, 337.

37 Ruiz CABrero 2003.

38 No es la única, pues al menos en una inscripción fragmentaria grabada sobre otra lámina se pide proteger al muerto, según señala FANTAR $(1970,18)$.

$39 \mathrm{Su}$ situación en este lado del monumento ha sido muy bien precisada por Almagro GorbeA (1978, 262; ID. 1983, 205) por varias razones: apareció caído en el lado Este a cierta distancia de la base del monumento y coincide su altura con la de los sillares correspondientes a la octava hilada.

40 La escena aparece bien enmarcada por tres de sus lados, habiendo desaparecido la moldura que contornea el friso por el lado izquierdo. No obstante, la composición simétrica de la representación indica que la escena no se extendía más por ese flanco, faltando sólo la moldura que lo limitaba.

41 Almagro Gorbea 1983, 205.

42 Olmos 1996, 105-106.

43 Fernández Rodríguez 1996, 313. 


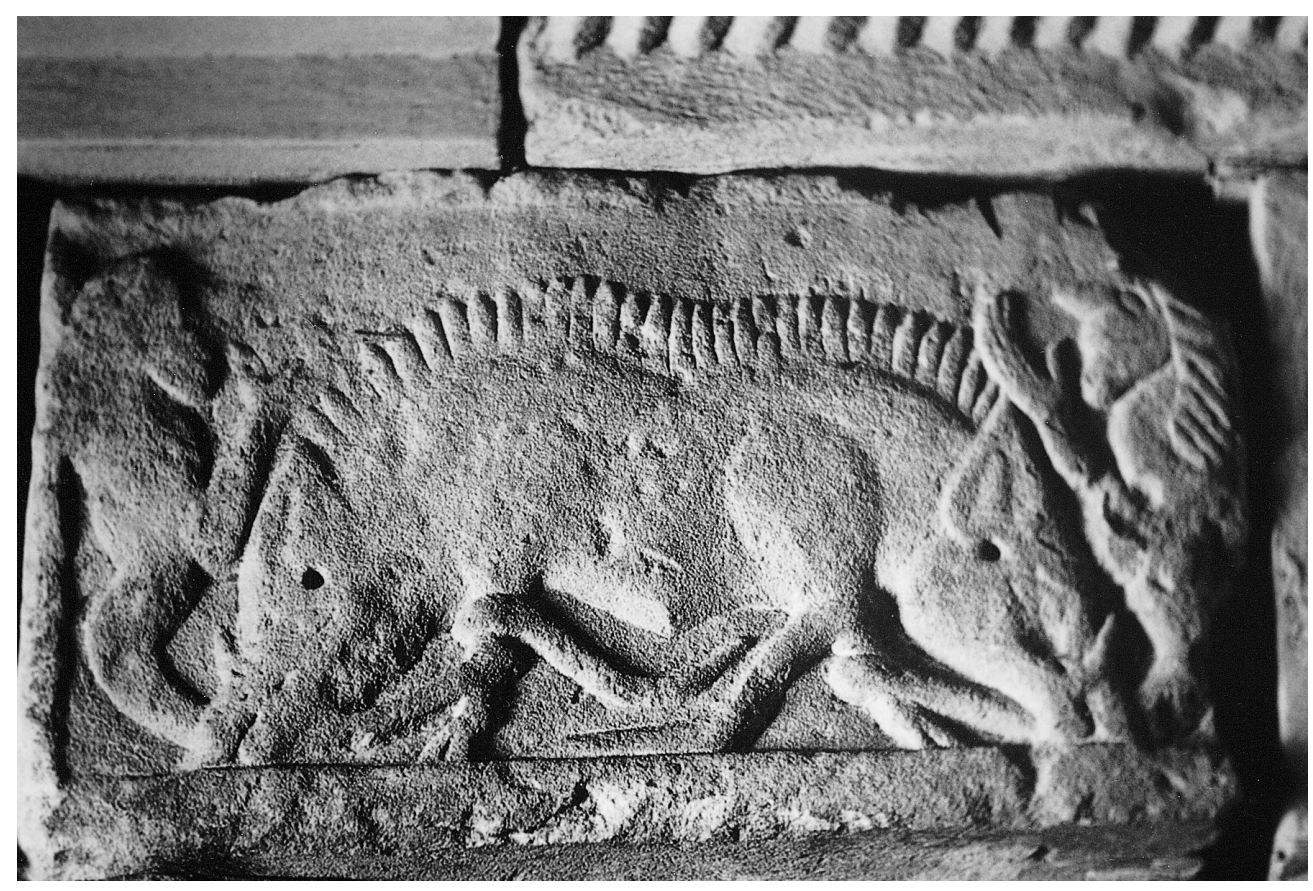

Fig. 2. Vista parcial del monumento de Pozo Moro instalado en el M.A.N.

que existe una oposición entre el mundo de la muerte, representado por el jabalí, y el mundo de la vida, los seres híbridos.

Hay que anotar dos cosas especialmente relevantes de las aportaciones de estos investigadores, por un lado que ambos tipos de seres tienen una relación con el mundo funerario y ctónico y por otro que no hay acción de lucha entre los seres monstruosos, pues la actitud agresiva es observable sólo en el jabalí, mientras los serpentiformes no presentan una acción de fuerza o violencia respecto al animal ni tampoco dan la impresión de defenderse. ${ }^{44}$

Creo que el friso debe conectarse con el del "banquete" por múltiples razones: encontrarse en el mismo lado del monumento y ser susceptible de interpretarse como una explicación complementaria respecto a éste. La significación funesta del jabalí, ya destacada por los especialistas que han tratado el tema, aparece bien atestiguada en el ámbito fenicio oriental. Allí vemos al jabalí como instrumento del deceso. Así ocurre con Tammuz (Adonis), el héroe/humano, "hijo de Chusor, rey de los fenicios", que la diosa Baalat Gubal (Señora de Biblos) toma como paredro tipo, tras volverlo a la vida después de ser destrozado por un jabalí enviado por el celoso esposo de la diosa cuando cazaba en los montes Líbano. ${ }^{45} \mathrm{Al}$ estar asociado a los seres ofidiformes, se

44 Olmos 1996, 106. El anguípede, en el mundo etrusco también tiene significación funeraria, aunque aparece en estelas tardías (BLÁzQUEZ 1992, 367-368).

45 Pseudo-Meliton, ed. Cureton 1855, 43-44; RiBICHINI 1994. 


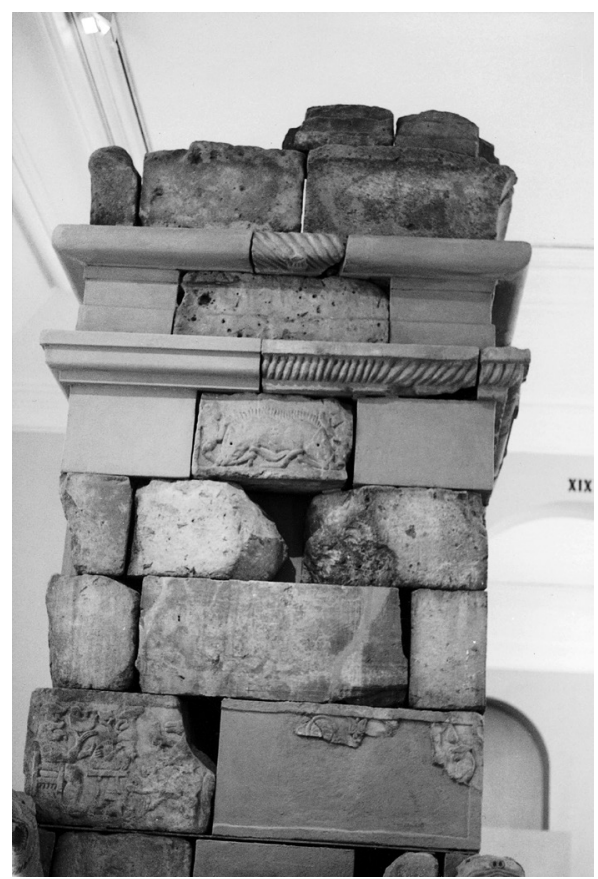

Fig. 3. Escena del “jabalí bifronte” (según Almagro Gorbea, 1983).

destacaría más aún esta vertiente concreta del jabalí para que no quepa duda sobre el significado de su presencia en el monumento. Lothan, Tunan, Arish, Ladón, Tiphón, etc., son nombres de seres con cuerpo humano y extremo de serpiente o simplemente serpientes que son enviados por la deidad que representa el Caos, o la deidad misma, a acabar con la vida del dios/héroe que establece el Cosmos en la literatura semítica y después en la griega.

El acto atribuible al jabalí "homicida" no debe considerarse incidental, como un caso de óbito concreto, sino que tiene un significado más general, de tránsito mortuorio al poder vincularse a los dos humanos representados en el friso inferior. Por un lado, el fiero y gigantesco animal doble con sus grandes colmillos enlaza perfectamente con la representación de los humanos descuartizados de la escena inferior, al poder imaginarse la acción desmembradora de sus colmillos y dientes. Esa conexión viene completada por la extraña representación de los dos jabalíes unidos por el tronco ${ }^{46}$ y que los seres ofidiformes sean gemelos, lo cual nos parece explicable por la necesidad de significar dos actos de muerte, al ser dos humanos diferentes los representados en el friso inferior.

Podemos ver aquí incluso una doble alusión a animales y seres estrechamente vinculados a la deidad que da muerte a Melqart, que conocemos sólo por su denomina-

46 No se puede hablar con propiedad de un jabalí bicéfalo. 
ción griega, Tiphón. ${ }^{47}$ Así, los seres serpentiformes no parecen dejar espacio a la duda sobre su vinculación con la deidad tifea, a su vez serpentiforme. Pero el jabalí también representa a la deidad maligna, pues este nos es conocido como el animal sagrado de Seth, ${ }^{48}$ el antagonista que acaba con la vida de Osiris, cuyo mito de dios muriente parece haberse trasladado al mundo fenicio, tocando especialmente a la figura de Melqart. ${ }^{49} \mathrm{La}$ vinculación se estrecha desde el momento en que Seth en su interpretatio graeca es 1lamado Tiphón, ${ }^{50}$ como el contrincante de Melqart. Esta conexión con el antagonista de Melqart de los seres que inflingen la muerte en el friso, subraya el papel arquetípico que juegan ciertos elementos del deceso y egersis del dios/rey de Tiro para ejemplificar el tránsito mortuorio y posterior acceso a la inmortalidad en un monumento que corresponde a la esfera de la realeza. Así pues, y al igual que en el friso inferior, percibimos también aquí una tradición genuinamente cananea parcialmente filtrada por una visión egiptizante, excelentemente mezclada y en una secuencia absolutamente pertinente, de seres que simbolizan el óbito en la escena superior y su continuación en la inferior donde se escenifica la exaltación refaítica por un lado y la extinción de la vida ultraterrena por otro.

\section{La deidad entronizada}

Fijemos ahora nuestra atención en la imagen de lo que se había considerado habitualmente como un único personaje entronizado con dos cabezas superpuestas. Recientemente J. Blánquez ${ }^{51}$ ha descartado que se trate de una divinidad simplemente bicéfala, sino que son dos individuos divinos. Para su argumentación ha sido determinante la acción del "mayordomo" que ofrece un cuenco de libación que sólo puede dar a esa segunda deidad, dado que la que está delante tiene ya ocupadas ambas manos, así el oferente pone de manifiesto al espectador la existencia de dicha figura semioculta. Se trata pues de una deidad a la que se ha de suponer dos cabezas paralelas y dos torsos con sus respectivos brazos o dos deidades gemelas.

Una primera aproximación nos lleva a valorar una deidad doble que aparece en la literatura ugarítica: thkmn w šnm, deidad doble o pareja divina íntimamente relacionada con el dios El. En un lecho de aparato de Ugarit, en la cara A conocida como "Le donateur giblite et ses dieux" 52 están representados en la placa $d$ dos fi-

\footnotetext{
47 Atheneo, IX 392d; Diogeniano, Prov. III, 49.

48 LIPINSKI 1995, 92.

49 Bonnet 1987, 125 y 141; ID. 1988, 188. No podemos seguir, sin embargo, la tesis de que Tiphón sea la transposición helena de Baal Saphón/Zeus Kasios, pues nada puede hacer entrever en esta deidad la figura de Tiphón, una discordancia ya destacada por distintos autores (entre otros Chuvin - YoyotTe 1986). Como muy bien señaló VIAN $(1960,18)$ Saphón no prefigura al Tiphón griego. Por su parte Filón de Biblos $(P E 1.10,9)$ pone de manifiesto de forma clara la existencia del Monte Casio gobernado por una deidad homónima, pero más adelante $(P E 1.10,26)$ hace de Tiphón una deidad marina que pone al lado de Ponto, el mar tempestuoso, y Nereo (Madid y Naharu respectivamente según BAumgarten 1981, 207) sin apreciarse ningún indicio de relación entre uno y otro ni por su ascendencia ni por sus características.

50 Hdt. II, 144 y 156.

51 BLÁNQUEZ 1999, 266.

52 Du Mesnil du Buisson 1973, 174 y pl. X.
} 
guras masculinas superpuestas de similitud exacta, en las que vemos a los gemelos thkmn $w \check{s} n m .{ }^{53}$

Sin embargo, Thakamún y Shunam son casi unos desconocidos para nosotros y sus funciones no han sido precisadas más allá de su vinculación con el dios supremo El, pues las tentativas por caracterizarlos no han convencido a todos. Se les ha visto un origen casita y se constata su no pertenencia al panteón oficial ugarítico, además de ser consideradas emanaciones del propio dios El ${ }^{54}$ Sin embargo ha sorprendido a los especialistas que sus nombres hayan aparecido en distintas tablillas de conteniendo ritual, tanto dentro de listas amplias de dioses ${ }^{55}$ como en un ritual de expiación general entre unas menciones globales a las divinidades que se encuentran en torno al padre de los dioses (El), sólo ellos son mencionados por su nombre ${ }^{56}$ En el texto sería visible su papel de intermediarios entre el pueblo de Ugarit y El y su "familia". ${ }^{57}$ Pero además la mención en el mismo del rey Niqmaddu (28) -el que va al Más Allá en KTU 1.161- haría extensible la expiación a los difuntos ${ }^{58}$ con lo que una cierta función ctónica quedaría subrayada.

Un mitema ugarítico ${ }^{59}$ nos presenta a los Rephaim, los manes regios o "héroes divinizados" llegados a un banquete divino, con toda seguridad en la residencia de El, que dura siete días y en el que participan algunas deidades, entre las cuales la más conocida es Anat. Allí se sacrifican abundantes víctimas, comen los más deliciosos frutos y se escancia el más preciado vino. En la séptima jornada se les une Baal, su patrón. ${ }^{60}$ Se trata, evidentemente, de la exaltación cultual de la divinización post mortem de los príncipes cananeos, aunque es lamentable que se haya perdido tanto el comienzo como el final de la tablilla, lo cual impide apreciar cual es su sentido último. ${ }^{61}$

53 Du Mesnil du Buisson (1973, 174-175) tentativamente los identifica con Shahar y Shalim, Aurora y Crepúsculo, aunque considera que sus atributos de harpé y arco con los que aparecen no se registran en la iconografía de estas deidades por lo cual considera dudosa esta identificación. Más si cabe al aparecer estos representados en la cara B amamantados por la diosa Athirat, un tema mitológico que la información textual ugarítica ha permitido aislar (Xella 1984, 88 y 131).

54 PARDEE 1988. No es imposible una equiparación con Isimud (Usmû, en acadio), dios con dos cabezas con funciones de ministro y mensajero, "de las dos caras" de Enki/Ea (BLACK - GrEEN 1992, 110), pues este último regularmente es asimilado a El/Dagán cananeo, así sucede en la traducción luvita de una inscripción fenicia de Karatepe (KAI 26 III).

55 Ejem. $K T U 1.41 / 87$.

$56 K T U 1.40$.

57 Olmo Lete 1992, 49, n. 58.

58 Olmo Lete 1992, 105, n 183.

$59 K T U 1.22$.

60 Olmo Lete 1998, 169-170.

61 El texto de esta tablilla ha sido relacionado generalmente con otras dos enormemente fragmentarias ( $K T U 1.20$ y 1.21), entendiéndose que parece describirse la invitación a los rephaim a sucesivos banquetes en palacios de ciertos dioses o rephaim de los cuales no se conserva el nombre, excepto el de uno de ellos, el de Danel (1.20 II), o bien la repetición con variantes de la invitación y su ejecución (Cf. Olmo LeTE 1981, 418419). No debe utilizarse a este respecto su última traducción (OLMO LETE 1998, 171) pues condensa en uno los cinco textos fragmentarios de $1.20 \mathrm{I} ; 1.20 \mathrm{II} ; 1.21 \mathrm{II} ; 1.21 \mathrm{~V}$. La mención de dicho nombre ha propiciado que se relacionara con el Poema de Aqhat, pero, como han señalado otros investigadores, en la tablilla que nos interesa (1.22) aparecen algunos personajes que no tienen cabida en el mito de Aqhat. Existiendo también, por otro lado, una cierta incongruencia entre el supuesto anfitrión mencionado en 1.20 II, el rey Danel, y el que 
En el banquete al que llegan los reyes muertos y divinizados se encuentran: "hombro con hombro, los dos hermanos, los que asisten a El, "con presteza"/ "los que cortan la muerte" (blsmt). ${ }^{62}$ Evidentemente la referencia a la disposición de los dos hermanos "hombro con hombro" (thm thkm b thkm) no sólo constituye una indicación de su condición gemela -lo que se corresponde con su representación en la placa de marfil que comentamos antes- sino también un midrash de su nombre, Thakamún. ${ }^{63}$ El papel en el proceso de inmortalización que se le puede atribuir a estos dióscoros de El a partir del texto sobre los rephaim y quizás en $K T U 1.40$ y su carácter de deidad doble permite considerar la existencia de un importante reflejo en la escena del friso de P.M.

Filón de Biblos ${ }^{64}$ menciona a los Dioscuros, a los que hace hijos de Sydyk (divinidad relacionada con la justicia), lo cual permite asegurar la existencia de divinidades de este género en el panteón fenicio pero no es fácil rastrearlos en el mundo siriofenicio hasta época tardía, ya con una fuerte impronta griega y una destacada significación astral que puede remitir a su vez a la vieja tradición cananea de los hijos estelares de El, Shahar y Shalim, la Aurora y el Ocaso, colocados bajo la protección de Shapash (sol) en los extremos del desierto. ${ }^{65}$

Los Dioscuros aparecen en monedas de Akko y Trípoli desde el s. II a.C. y de otras ciudades de la costa fenicia. ${ }^{66}$ También en el Norte de África se encuentran representados en monedas con leyenda púnica de Útica del s. II a.C. donde aparecen las dos cabezas laureadas de los Dioscuros y dos estrellas. ${ }^{67}$ En monedas púnicas atribuidas a Rusicade aparecen en el anverso las testas de los Dioscuros, también con estrella encima y en el reverso dos caballos a galope con la leyenda púnica $A S G .{ }^{68}$ En algunas de estas monedas aparecen flanqueando a Astarté lo que E. Lipinski ${ }^{69}$ interpreta como al servicio de la diosa, donde estos simbolizan la renovación constante de la vida o la eternidad cósmica lo que concuerda con el papel desempeñado por la deidad doble del friso que renueva la vida del difunto. Estos, según la tradición clásica, obtuvieron de

parece ser el anfitrión del texto que nos interesa (KTU 1.22) el propio dios El, rodeado de su corte de dioses, lo que indica que se trata de un banquete en su residencia. Como han propuesto VirollEaUd $(1941,30)$, Driver $(1956,9)$, Dressler $(1976,19-20)$ y Gibson $(1978,27)$, se podría incluir en el ciclo de Baal y no en el de Aqhat.

62 KTU 1.22 I; trad. Olmo Lete 1998, 172. Olmo Lete $(1981,422 ;$ ID. 1998, 172) prefiere traducir blsmt con el sentido "con presteza", seguramente siguiendo a CAQuot, Sznycer y Herdner (1974, 474, n. r) que relacionan el término con $l s m$ "courir", de tal manera que aunque el sustantivo no está atestiguado, lsmt debería tener el sentido de "course" o de "vitesse". Para otros tendríamos la negación $b l$ unida a la denominación de muerte, $m t$, lo que ha propiciado distintas lecturas relacionadas con el mundo funerario (véase OLMO LETE 1981, 422-423), empezando por Virolleaud $(1941,19)$ que lo relaciona con balsamatu "embaumement" en ar. (Olmo Lete 1981, 527), lo que seguramente ha permitido su consideración como un epíteto relacionado con la resurrección. Así tiene sentido que "los que cortan la muerte" sea presentada como alternativa lo que parece especialmente pertinente por el contexto.

63 Olmo Lete 1992, 49, n. 58; ID. 1998, 173, n. 6.

64 Filo. P.E. I, 10, 40.

65 KTU 1.23; CAQUot - SZNYCER - Herdner 1974, 357.

66 Du Mesnil du Buisson 1973, 108-110 y pl. V; Destrooper-Georgiades 1995, 158 y pl. 11, 33; Hermary $1992,131$.

67 MAZARD 1955, 159-160.

68 Mazard 1955, no 536 y 537; E.B. 1995, 2351.

69 LIPINSKI 1995, 283. 
Zeus, su padre, la autorización de pasar alternativamente un día en el infierno y otro en el Olimpo. Personifican, pues, el paso alternativo del dominio de la vida al de la muerte, de ahí su presencia frecuente en estelas funerarias norteafricanas de tradición púnica.

Podríamos tener la pervivencia de la vieja denominación semita de una de estas deidades en un bajorrelieve de Beja -a $80 \mathrm{~km}$ de Útica- donde se representan siete divinidades líbico-beréberes, algunas de las cuales parecen transferidas desde el mundo púnico y cuyo nombre aparece debajo. En los extremos del friso están con sus respectivas monturas dos divinidades asimiladas a los Dioscuros,${ }^{70}$ son Macurtam y Iunam. Aunque el primero se documenta en otros epígrafes africanos, ${ }^{71}$ Iunam no vuelve a aparecer ${ }^{72}$ y su nombre parece muy próximo a Shunam, el segundo dioscuro de El, lo que podría ser un indicio de la pervivencia, muy tenue, de las antiguas deidades, igual que sucede con la conservación de la vieja titulatura de la Edad del Bronce de El en una inscripción tardía de Leptis Magna. ${ }^{73}$

Los Dioscuros aparecen también como acólitos de Saturno africano frecuentemente, ${ }^{74}$ por ejemplo en la estela Boglio, de Siliana, Túnez, estos aparecen rodeando a Saturno que se apoya sobre un toro. Respecto a lo cual es necesario tener en cuenta que éste traduce al Baal Hammón cartaginés que a su vez recoge numerosas funciones del viejo El cananeo. ${ }^{75}$

A primera vista y a falta aparentemente de otra divinidad de aspecto realmente doble o gemelos en el mundo sirio-fenicio de la Edad del Hierro a la que se pueda atribuir la función ctónica que aparece reflejada en el friso de P.M. habría que relacionarlas con estas emanaciones de El. Sin embargo, la representación entronizada de los mismos nos hace sospechar un proceso de identificación con el propio dios supremo en su faceta de juez en el Más Allá. El aspecto dúplice de El/Kronos es destacado por Filón de Biblos ${ }^{76}$ que atribuye a Taauto (Tot) el idear para Kronos cuatro ojos, dos abiertos y dos cerrados y sobre los hombros cuatro alas, dos como si estuvieran volando y dos como si estuvieran quietas. Una apariencia doble que según Filón remarca su realeza y su soberanía sobre los demás dioses, los cuales contarían sólo con dos alas. ${ }^{77}$ La dualidad es una característica muy acentuada de la religión cananea, en la que se registra un particular gusto por las denominaciones dobles, los apelativos dobles y las funciones dobles de los dioses, así como la asimilación entre divinidades, la equiparación de dioses entre dos panteones, el cananeo y el amorreo, etc. $\mathrm{o}$ algunas divinidades gemelas.

70 CAMPs 1954; E.B. 1995, 2350.

71 Macurtam aparece en la tríada líbico-beréber de Henchir Ramdan con el nombre de Vacurtum entre dos diosas (CIL VIII 14444).

72 Cf. Camps 1995, 2329.

73 Levi Della Vita - Amadasi Guzzo 1987, 13.

74 E.B. 1995, 2351.

75 En último lugar, cf. SANMARTín 1999, 21.

76 Filo. P.E. I, 10, 36-37.

77 A continuación desarrolla Filón una explicación evemerista (BAUMGARTEN 1981, 226), como un símbolo de que aunque durmiera, vigilaba y, aunque estuviera despierto, reposaba; y respecto de las alas igualmente, puesto que descansando volaba y volando descansaba. 
En el mitema de la lucha de Baal contra Mot (muerte) El es repetidamente llamado mlk ab šnm (Rey, padre Shunam) ${ }^{78}$ lo cual parece mostrar un vínculo con šnm, una de sus emanaciones divinas mentadas. Ginsberg ${ }^{79}$ en su día prefirió transcribir "Father Shunem", mostrando así la inseguridad que planteaban las distintas propuestas de traducción. ${ }^{80}$ Para algunos $a b$ šnm es "padre de años", pero Caquot, Sznycer y Herdner ${ }^{81}$, que presentan la discusión, entienden que el plural del nombre ugarítico $̌ n t$ (año) tiene la forma femenina šnt y no la masculina como el hebreo bíblico, ${ }^{82}$ lo cual nos parece evidente en KTU 1.12 II 44, donde el término $̌ n t$ contextualmente parece bien transcrito por "años", mientras, tres líneas antes (41) šnm se traduce también por "años" a pesar de que falta la palabra que le precede lo que no hace evidente en este caso dicho sentido. A este propósito deberíamos tener en cuenta el significado de šnm en fenicio, "dos" (cardinal) o "segundo" (ordinal), ${ }^{83}$ lo cual remarcaría el carácter dual de El y haría coherente en su arcaísmo la información de Filón de Biblos y evitaría señalar contradicción con la herencia cananea. ${ }^{84}$

En suma todo permite asimilar la deidad doble que señorea el friso de P.M. en el que va a procurar la inmortalidad a un humano con el propio dios El o con sus dos asistentes a los que este habría procurado la función de "cortar la muerte".

\section{En la morada de El/Dagán}

El tiene una escasa presencia en el mundo fenicio posterior, donde permanece el uso cananeo de $i l$ como denominación genérica de divinidad. Así sólo raras inscripciones mencionan la vieja titulatura $I l$ qn'rs . La razón hemos de verla en un complejo proceso de sincretismo en el que participan El, Dagán y Baal Hammón, los tres identificados sistemáticamente con Kronos. ${ }^{85}$ En los textos mitológicos de Ugarit, Dagán aparece sólo mencionado como referencia de la filiación de Baal, ${ }^{86}$ donde no se le atribuye otro papel, lo que parece asegurar precisamente su asimilación con El. Según G. Del Olmo Lete "si no hay duda posible de la identificación de Baal y Hadad

$78 K T U 1.5$ VI 2; 1.6 I 36. En otras partes de la epopeya Ilu recibe otros apelativos distintos.

79 Ginsberg 1969, 133, 137, 139 y 140.

80 Otras interpretaciones del mismo son: "padre de los excelsos"/ "de la altura"/ "el más glorioso" (OLmo LETE 1981, glos. 631).

81 Caquot - Sznycer - Herdner 1974, 59.

82 Estos mantienen en suma la lectura de Ch. Virolleaud sólo en razón de una representación de Ilu como un hombre con barba sentado en un trono en un relieve ugarítico (CAQUOT - SZNYCER - HERDNER 1974, 59; CAQUOT - SZNYCER 1980, 12 y pl. VII).

83 KAI 137; 130. Cf. HaOfTIJZer - Jongeling 1995, 1176-1177; Krahmalkov 2000, 474.

84 Una contradicción manifestada por BAUMGARTEN $(1981,225-226)$.

85 Aunque Filón de Biblos (PE 1.10, 16 y 25) hace de El y Dagán hermanos, LiPINSKi (1995, 60, n. 12) entiende que la asimilación de El y Kronos en este autor debe corresponder precisamente a la identificación arcaica de Kronos con Dagán. El Etymologicum Magnum (52) señala que Dagón es el nombre dado a Kronos por los fenicios y por su parte si en las inscripciones de Karatepe El es identificado con Ea (KAI 26 III), ello explicaría que Beroso $(F G H$ 680, fr. 4,14) llame Kronos a Ea. Por su parte RiBichini (1996) presenta la extraordinaria complejidad de las asimilaciones con Kronos de estas divinidades.

86 KTU 1.2 I 19; y 35; 1.5 VI 24; 1.6 I,6; 52; 1.10 III 14 y $34 ; 1.12$ I. 
no debería haberla entre Ilu y Daganu" ${ }^{87}$ entendiendo que Dagán pertenecería al sustrato cananeo y El al amorreo, correspondiendo a una misma deidad tanto en el mito como en el sistema teologal. ${ }^{88}$

Quizás la razón de la referencia filial de Baal como hijo de Dagán estribe en que Baal/Hadad sea el dios atmosférico del Saphón y como tal es conocido en los textos litúrgicos de Ugarit, pues, siguiendo a E. Lipinski, ${ }^{89}$ el monte Saphón se considera un apéndice de la cadena montañosa del Amanus, el dominio de Dagán. Precisamente en el primer milenio "Señor del Amanus" (Baal Hammón) habría suplantado el nombre propio de Dagán ${ }^{90}$ y el de El. ${ }^{91}$ Dicha relación se puede percibir en la inscripción de un amuleto de Tiro del s. VI a.C. ${ }^{92}$ donde precisamente Baal Hammón precede a Baal Saphón, lo que indicaría la pervivencia de la tradición cananea tanto en Oriente como en Occidente, pues la práctica desaparición de El/Dagán no podría explicarse más que por su ocultamiento tras la figura de Baal Hammón ${ }^{93}$ como atestiguan las raras menciones en Oriente ${ }^{94}$ y una única referencia en el Mediterráneo Occidental procedente de Leptis Magna. ${ }^{95}$

En este horizonte de sincretismo debemos situar las diferentes identificaciones del personaje de P.M. realizadas por M. Almagro Gorbea ${ }^{96}$ y J. M. Blázquez. ${ }^{97}$ Así para el primero el personaje entronizado es Moloch o Kumarbi-Kronos. ${ }^{98}$ Por su parte J. M. Blázquez incide en la misma línea al identificarlo con Kronos. Ellos ya han percibido claramente la relación con el Más Allá de estas deidades y han centrado muy adecuadamente la discusión en torno al rey de los dioses de la segunda generación. ${ }^{99}$

"El, poseedor de la tierra" (Il qn ,rș), ${ }^{100}$ tiene su residencia, exactamente "en la fuente de los ríos, en medio del curso de los dos océanos" donde tiene lugar la hiero-

87 Olmo Lete 1981, 70.

88 El binomio El/Dagán aparece destacado en textos rituales (KTU 1.118 y 1.47) lo cual se corresponde con la ausencia del último en el panteón recogido en varios rituales sacrificiales donde la lista de dioses es muy prolija (KTU $1.41 ; 1.87 ; 1.39)$, lo que sería inexplicable si fuera una deidad distinta, y menos tratándose, por otra parte, del padre de Baal.

89 LIPINSKI 1995, 254.

90 Olmo Lete 1981, 69; ID. 1992, 40 y 56; ID. 1998, 23. El primer testimonio es de la segunda mitad del s. IX a.C. en Zincirli en la región del Amanus (KAI 24) (LIPINSKI 1995, 173, 252 y 254-255).

91 Recientemente SANMARTín 1999, 21.

92 BordREuIL 1986, 82-86.

93 Sobre Baal Hammón en Cartago véase por último Marín CEBAllos 1999, 71-72.

94 Uno de los pocos ejemplos es una inscripción bilingüe de Karatepe (KAI 26 III 18).

95 Levi Della Vita - Amadasi Guzzo 1987, 13.

96 Almagro Gorbea 1993-1994, 114.

97 BlÁzQuez 1998-1999, 115; ID. 2001, 205-206. Aunque tal identificación tiene más que ver con su idea de que la escena representa a Kronos devorando a sus hijos, un mito documentado en la tradición griega pero no explícitamente en Filón de Biblos.

98 Kumarbi seguramente por el estilo neohitita de los frisos.

99 En las tres teogonías más importantes del Mediterráneo oriental la sucesión de dioses en posesión de la realeza se compone de tres generaciones, en las cuales Kumarbi, Kronos y El corresponden a la segunda: Anu-Kumarbi-Dios de la Tormenta en la Hitita, Uranos-Kronos-Zeus en la griega y Uranos-Kronos/El-Belo/ Baal en la fenicia (Filó, PE 1.10, 1-30) (Pecchioli Dadd - Polvani 1990, 127).

100 Un mito del norte de Siria del segundo milenio traducido al hitita nos lo presenta como d $E l-k u-n i-i r-s ̌ a$, (Goetze 1969, 519; CAquot - SznyCER - Herdner 1974, 57-58). Titulatura que permanece en un epígrafe de Karatepe y otro de Leptis Magna de los siglos VIII y II a.C. respectivamente (KAI 26 III 18; Bron 1979, 186187; Levi Della Vita - Amadasi GuZzo 1987, 13 y 45-47). 
gamia de El y las dos "consagradas". ${ }^{101}$ Es donde Kronos (El) amputa los genitales a Uranos en Filón de Biblos ${ }^{102}$ "muy cerca de unas fuentes y unos ríos". ${ }^{103}$ Dicho dominio del 'rș debemos relacionarlo con la referencia a los reyes muertos en el culto de Ugarit como los rpu rṣ , los rephaim de la "Tierra" a los que Shapash acompaña en su viaje. ${ }^{104}$ Allí residen también dioses si no son los propios rephaim, los ilm 'rṣ. ${ }^{105}$ En todo ello se aprecia el carácter ctónico de esta residencia divina y de las deidades que la habitan entre las que se encuentran los rephaim. ${ }^{106}$ La misma tiene consideración de ciudad divina en $K T U 1.20$, pues es el destino de los reyes difuntos en el conocido "Poema de los rephaim" a los que se invita y donde tendrá lugar el banquete que prepara El. ${ }^{107}$

La deidad, el escenario y sus moradores se corresponden con los que están presentes en la teogonía griega orientalizante ya antes del siglo VII a.C. en la que se ha visto claramente un origen levantino. ${ }^{108}$ En la Ilíada ${ }^{109}$ se señala que por orden de Zeus, Kronos y Japeto residen en los remotos confines de la tierra y el mar donde no gozan del brillo del Sol, como resultado de su derrota. Un mito que según Crates es fenicio, ${ }^{110}$ lo cual está en consonancia con el origen levantino reiteradamente señalado de Japeto (Jafet) el otro residente de dicho confín. ${ }^{111}$ En el mismo sentido se define Talo ${ }^{112}$ que se refiere a la "Historia fenicia" de la lucha entre Zeus y Kronos, en una muy estrecha relación con la antiquísima Historia fenicia traducida al griego por Filón de Biblos, donde se encuentra la Historia de Kronos que refiere la lucha por el trono de los dioses entre Uranos y su hijo Kronos/El. ${ }^{113}$ Abunda en ello Hesíodo al señalar que Kronos fue liberado finalmente por Zeus (tras la teomaquia que los enfrentó) y se convirtió en rey de las islas de los bienaventurados, lo cual permite a Píndaro ${ }^{114}$ indicar que los hombres perfectos se dirigen en su viaje postrero hacia "la torre de Kronos", la morada de los bienaventurados. ${ }^{115}$

\footnotetext{
101 KTU 1.23; CAQUOT - SZNYCER - Herdner 1974, 357.

102 Filo. P.E. I, 10, 29.

103 Du Mesnil du Buisson 1973, 2.

104 KTU 1.161; Olmo Lete 1992, 131.

$105 K T U 106$.

106 El carácter ctónico de Dagán ya fue apreciado por HeAley (1977).

107 Olmo Lete 1992, 115. De ello podría existir una importante pervivencia en las paredes de una de las tumbas de Gebel Mleza (Túnez), donde aparece la ciudad almenada a la que llega el alma (FANTAR 1970, 35).

108 Las significativas analogías entre la Teogonía de Hesíodo y el ciclo de Kumarbi (HAAs 1982, passim) ha permitido señalar que la transferencia de dicho esquema norsirio pudo tener lugar ya en el $2^{\circ}$ milenio a.C. a través del mundo hitita, o mejor una transmisión aramea posterior como es posible apreciar por algunos indicios (BURKERT 1992, 93; ID. 1999, 16-17). Por su parte LiPInSKi $(1995,256)$ ve en el esquema teomáquico del mito de Kumarbi y el de Kronos en Filón de Biblos (PE 1.10, 15-33) una tradición siria común.

109 Hom. Il. VIII, 477.

110 Gr. 4 a, b; THA II a, 15 n 24.

111 En último lugar BuRKERT 1992, 177, n. 37. Sobre Jafet como antepasado de los fenicios véase TSIRKIN

112 FGH $256 \mathrm{~F} 2$.

113 PE 1.10, 15-30.

114 Pi. O. 2.70.

115 Burkert 1999, 66.
} 1991. 
Quizás precisamente por su morada oceánica se expliquen ciertas prácticas fenicio-púnicas que se pueden relacionar con el mito. Así el texto del Periplo de Hannón había sido fijado en el templo de Kronos de Cartago, ${ }^{116}$ seguramente porque el dominio en el que se había internado el navegante era el de Kronos y por la misma razón las pieles de las Gorgadas-Gorillas capturadas por el cartaginés en el mismo ámbito oceánico fueron también consagradas en el mismo templo. ${ }^{117}$ Por su parte, el Kronion de Gades, ${ }^{118}$ era uno de los tres santuarios más importantes de la ciudad, cuya ubicación en el extremo más oceánico de la isla puede tener una fuerte carga simbólica en relación precisamente con la sede del dios.

En suma, la residencia del Padre de los dioses es concebida como la última morada de los rephaim una vez sustanciado su proceso de inmortalidad. En el plano cultual dicha trasmigración debía ser propiciada por un ritual realizado en el templo que en el caso ugarítico es, evidentemente, el de El/Dagán, y del cual veríamos la secuela en el plano divino/mítico en el propio friso.

\section{Un ritual de tipo pgr}

Dos estelas halladas en el templo de Dagán/El -el más importante de Ugarit, situado junto al de Baal- dejan constancia de una ofrenda de carácter fúnebre a Dagán por parte de la esposa real en la primera y por un hijo de rey en la segunda. ${ }^{119}$ Consisten ambas en un ofrecimiento de $p g r$ y de un buey sacrificado. G. del Olmo Lete remite a las tradiciones de Mari y Emar, donde en la primera Dagán es "Señor de las ofrendas pagr $\bar{a} \bar{u}$ / los cadáveres" y de donde procede un documento sobre su celebración con ocasión de la muerte del rey Sümū-Epuh de Alepo. Según el filólogo en las dos estelas se distingue claramente entre $p g r$ (cadáver/restos mortales) y la víctima animal sacrificada $(a l p)$ que le acompaña, lo que determina que el primero se refiera al muerto humano, lo cual por otro lado está ampliamente documentado en Mari. ${ }^{120} \mathrm{El}$ ritual permite trasmigrar al difunto al Más Allá, a "congregarse con los muertos ancestrales", en correspondencia con la antigua tradición cananea de Ebla y Emar del kispum-pagră $\bar{u}$. Ambas estelas en el santuario de Dagán/El constituyen los exvotos que muestran la importancia de este ritual funerario, que excede el de cualquier otra ofrenda, cuya realización no queda perpetuada en un monumento epigráfico. Este significado de $p g r$ queda remarcado también en una lista de ofrendas a dioses y reyes divinizados de marcado carácter ctónico donde la deidad solar, la que conduce a los difuntos al Más allá es llamada Shpsh pgr. ${ }^{121}$

116 Hano 1.

117 Hano 18. Sobre este pasaje véase Desanges 1983; LipINSKi 2001.

118 Str. III, 5, 3.

119 KTU 6.13 y 6.14. Trad. Olmo Lete 1996, 83; CAQUOT - SZNYCER 1980, 3 y pl. XX.

120 Seguimos en toda esta explicación lo señalado por Olmo Lete (1996, 82-86). Otros textos sobre ofrenda del sacrificio pagru en Mari (Moran 1969, 623-625).

121 KTU 1.102; Olmo Lete 1992, 46. 
Este ritual funerario de carácter regio se conserva durante el primer milenio, pues según el investigador al que seguimos ${ }^{122}$ hay que tomar en este sentido una noticia del profeta Ezequiel ${ }^{123}$ sobre la profanación del templo de Yahvé en Jerusalén con las "prostituciones" y los cadáveres de los reyes.

Debemos detenernos ahora en algo muy significativo en las dos estelas del santuario de El/Dagán: junto al ofrecimiento del cadáver ( $p g r)$ tiene lugar la ofrenda de un único buey al dios Dagán. El trasunto divinal de la ofrenda doble es la que aparecería en la escena divina de P.M. donde vemos ya al difunto en el cuenco y el jabalí sacrificado sobre la mesa que toma la deidad entronizada. Lo que nos lleva a valorar que el escrupuloso respeto de dicha práctica cultual terrenal propicia la inmortalidad del personaje, que podrá así ser "establecido" (bebido) rapha por la deidad y no devorado como el animal ofrecido y que se encuentra ya en la mesa del banquete divino (de ahí la necesidad de la ofrenda doble). ${ }^{124}$ Ello se corresponde en el antes mencionado párrafo de Ezequiel ${ }^{125}$ con la afirmación de que por tales abominaciones Yahvé los ha devorado, así el filtro postexílico ha transformado precisamente en causa de su extinción ultraterrena lo que se quería evitar con el ritual $p g r$, que los cadáveres de los reyes (bepigrê malkêhem) fueran devorados en vez de bebidos/establecidos rapha por Yahvé, aquí claramente asimilado con el dios cananeo El/Dagán.

\section{Entre seres zoomorfos}

El juicio representado en P.M. incorpora un escenario de connotaciones infernales lo que es subrayado por la apariencia zoomorfa de los personajes divinos, todo lo cual supone una novedad con respecto a la imagen cananea de la "morada de reclusión" de Mot, de la cual no hay noticia de su consideración de sede del juicio divino ni tampoco de la presencia de un tribunal de dioses en su "ciudad fangosa", lo que parece extensible al resto del mundo semita del segundo milenio y parece perdurar aún en textos de origen mesopotámico conservados en el milenio siguiente. ${ }^{126}$

\footnotetext{
122 Olmo Lete 1996, 84.

123 Ez. 43, 7-9.

124 Mientras, el humano cuya existencia ultraterrena está siendo anulada no viene acompañado de ninguna ofrenda animal.

125 Ez. 43, 8.

126 En el mito de la "lucha entre Baal y Mot" su morada es subterránea, a la que para descender es necesario levantar el monte que la cubre (KTU, 1.5 V, 13) (CAQUot - SzNYCER - Herdner 1974, 248; Olmo Lete 1981, 220), es mazmorra/sepulcro/sumidero (Olmo LeTE 1981, 213-214) /abîmes (CAQuot - SzNYCER -HERDNER 1974, 241, 1) (1.5 I 7); (1.5 II 15) ciudad fangosa (Olmo Lete 1981, 217) / cité abyssale (CAQUOT - SzNYCER Herdner 1974, 245) / City Hamriya (Ginsberg 1969, 139), y ciénaga su trono (Olmo Lete 1981, 217) / le trou, son patrimoine (CAQUOT - SzNYCER - Herdner 1974, 245); (1.5 V 15) morada de reclusión de la "tierra" (Olmo LETE 1981, 220) / “demeure de réclusion souterraine" (CAQUOT - SZNYCER - Herdner 1974, 248); (1.5 V 16) abismo (Olmo Lete 1981, 220) / "en terre" (CAquot - Sznycer - Herdner 1974, 248) / "depth of the earth" (Ginsberg 1969, 139). Similares consideraciones se pueden hacer del Sheol, el infierno hebreo más antiguo (Isaías, 14, 9) (Podella 1991 150). En el s. VII a.C. la visión del infierno del príncipe asirio Kumma es igual de dantesca (ANET, 109-110; LARA Peinado 2002, 311-316). Allí se encuentran Nergal y Ereshkigal, la reina de los infiernos, Namtar, el visir del Mundo Inferior. Allí se hallan en total quince dioses infernales de atributos aterradores muchos de los cuales tienen cabeza animal pero pies y manos humanas. En el ámbito babilónico
} 


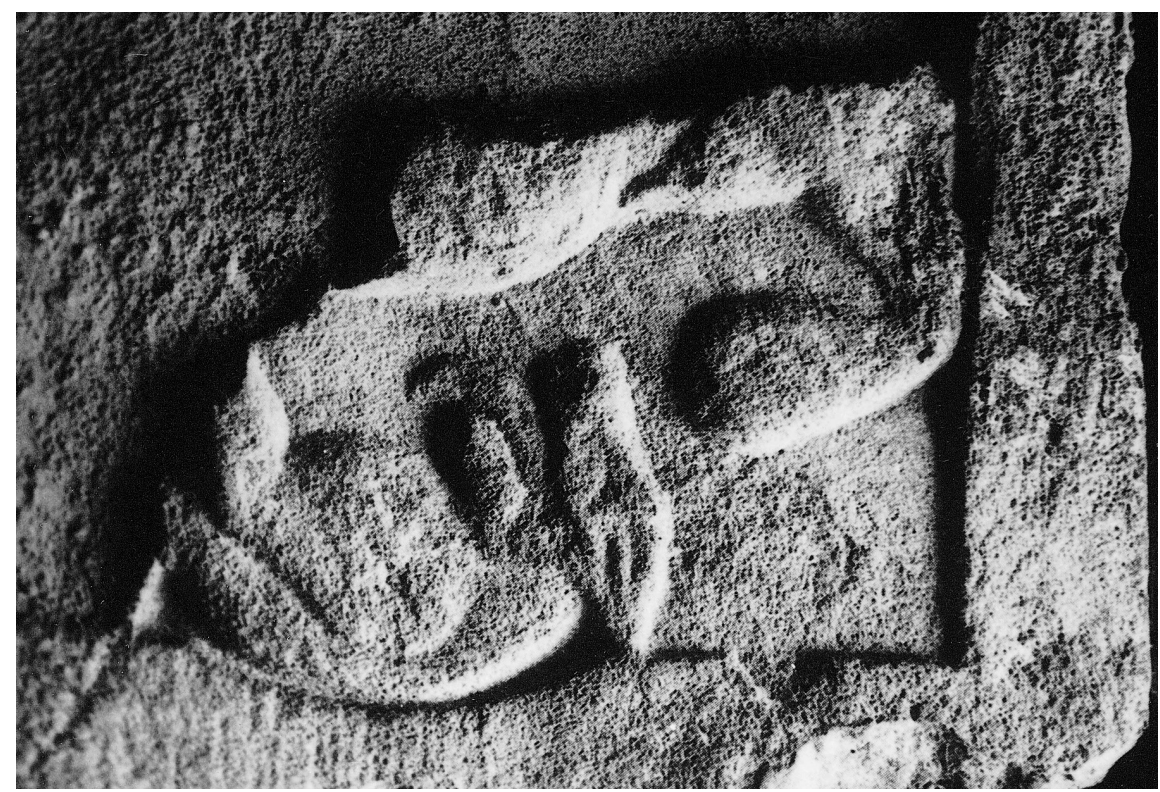

Fig. 4. Esquina izquierda del friso del "banquete" (según Almagro Gorbea, 1983).

Ya señalamos al principio la procedencia egipcia de la escena "aniquilatoria" del friso de P.M., un influjo que debemos hacer extensible al escenario infernal representado que queda remarcado por la apariencia animal a la vez que humana de los seres que lo pueblan de un extremo al otro (fig. 4). La sala del Juicio de Osiris se encontraba entre el quinto y sexto recinto del Duat (infierno) según los textos escatológicos egipcios a donde llegaba el difunto tras hacer el viaje nocturno de Re, la deidad solar, tal como se cuenta en el "Libro de las Puertas" o en el "Libro de Am Duat" ("del que está en el infierno"). ${ }^{127}$ Parecería, pues, pertinente que la divinidad inmortalizadora cananea fuera colocada en dicho escenario de juicio infernal por una acentuada influencia egipcia en el mundo sirio-fenicio, muy bien documentada por otra parte. Así sucede que el Dagán cananeo en un poema asirio tome asiento con Nergal y Mišaru como jueces de los muertos cuando estos alcanzan el inframundo. ${ }^{128}$

Precisamente la penetración de ciertos aspectos de la escatología osiríaca en los ambientes metropolitanos y coloniales fenicios parece bien documentada a través de las láminas egiptizantes guardadas en porta-amuletos que se han hallado en sus necrópolis. ${ }^{129}$ En ellas se combinan precisamente representaciones de dioses con ca-

durante la Edad del Hierro, se reconoce bien el mismo carácter en el "Poema de Erra", pues desde el Apsu podrán subir los demonios y los terribles Anunnaki (170-175; Trad. Jiménez Zamudio 1998, 61-62); véase también BotTero 1985, 233). Un poema acadio conocido en los palacios neohititas (BURKERT 1992, 109-114).

127 James 1960, 207; Scandone Matthiae 1991.

128 BLACK - Green 1992, 56.

129 Es a partir del s. IX a.C. -durante la dinastía XXII- cuando se produce en Egipto la estandarización de estas representaciones (Vercoutter 1945, 319). Su transferencia a la concepción fenicia del Más Allá se 
beza de animal, dioses completamente humanos y animales divinos aunque en actitud humana que se corresponden de alguna manera con las imágenes del friso de P.M. ${ }^{130}$ Unas láminas que describen con ellos, los decanos, los dioses guardianes, el cielo nocturno por el que se desplaza la deidad solar, ${ }^{131}$ una parte importante del esquema escatológico fenicio. Las inscripciones personalizadas halladas en algunas de estas láminas se refieren precisamente al momento crítico del juicio como vemos en la hallada en una tumba de Moraleda de Zafayona, en el interior de Granada, donde se solicita el auxilio del dios Eshmún en el juicio del alma frente a la "devoradora" para obtener así la inmortalidad. ${ }^{132}$ Vemos, pues, en la composición de P.M. en lo relativo al escenario infernal del juicio y la representación animal/divina el fondo egipcio que se aprecia en esta temática en la escatología fenicia.

No obstante la correspondencia no es absoluta, pues la iconografía en P.M. no es de estilo egiptizante sino claramente neohitita, lo que no es óbice para confirmar también que en esta última tradición tampoco hemos encontrado ningún paralelo estricto de las figuras representadas y menos aún alguna escena semejante. Ello obliga a considerar que el discurso teológico se separa claramente de los aspectos estilísticos, que, por otra parte, se corresponden con el estilo escultórico general del monumento. De tal manera que, así como en los otros frisos se representan con el mismo lenguaje iconográfico temas mitológicos que corresponden a elaboraciones mayoritariamente ajenas a dicho contexto cultural, en este caso concreto sucede otro tanto.

Seguramente las representaciones de daimones del ámbito asirio, pero a través del filtro neohitita, parecen haber influido algo en la iconografía del friso aunque no en la concepción. En una de las placas de bronce asirias consideradas de exorcismo aparecen bajo los emblemas de los siete grandes dioses una fila de siete deidades con cabeza animal, carnero, ave, serpiente, león, zorro (?) etc., ${ }^{133}$ pero vestidas con largos ropajes; son seres protectores en actitud amenazante frente a los demonios del registro inferior, mientras, en medio se encuentra el enfermo que pretenden arrebatar los últimos. ${ }^{134}$

Así, pues, la depurada escatología egipcia que veíamos afectar al tema del juicio divino en su vertiente de aniquilación parece extenderse a las connotaciones infernales de la escenificación, pues no en vano constituyen un todo unitario, apartándose en este aspecto de la vieja y menos elaborada tradición cananea.

produce poco después. Quizás los más antiguos estuches portadores de estos rollos remonten a fines del s. VIII o bien al VII a.C. (Necrópolis del Cerro San Cristóbal, Almuñécar) pero su mayor difusión se registra entre los siglos VI y IV a.C., época de la que son los procedentes de Cartago, Chipre y Tiro (Quillard 1971-1972, 17, 1-32).

130 Como ya señalamos en unas páginas atrás el daimon del "tormento" del friso recuerda a uno de los personajes divinos representados en la lámina egiptizante de Ghar Barka (Malta).

131 MaAss-Lindemann - MaAss 1997, 275.

132 Ruiz CABrero 2003.

133 Compárese la cabeza de zorro (?) con oreja apuntada de este bronce y el ser representado en el extremo del friso también con oreja apuntada. Sin embargo, la larga vestimenta de esta como de las demás figuras del bronce constituye un elemento de divergencia, pues en el friso sólo el "mayordomo" o "visir" lleva ropaje largo y bonete, seguramente con el fin de poder ser identificado como tal.

134 ANET, Supl. 1969, $\mathrm{n}^{\circ}$ 660, 215 y 328. Quizás se trate de los Sebittu (los siete), grupo de deidades benéficas cuyo poder controla el de los demonios (BLACK - GREen 1992, 162 y 181). 


\section{Cuestiones de estilo y cronología}

Una de las primeras cosas que es necesario constatar, respecto a los frisos que analizamos así como del resto, es el acuerdo general que existe entre los investigadores acerca del origen no indígena del taller que construyó el monumento. ${ }^{135} \mathrm{~A}$ este respecto, ha sido prácticamente unánime la aceptación de la tesis del profesor Almagro Gorbea ${ }^{136}$ que atribuye a un taller peninsular que trabaja al estilo neohitita, pero donde se aprecia un filtro fenicio evidente, planteamiento con el que también estamos de acuerdo.

M. Almagro Gorbea ${ }^{137}$ encuentra una especial relación con los relieves de los ortostatos de Tel Halaf y de Karatepe, aunque también aprecia muy oportunamente una relación con las escenas representadas en las páteras repujadas y los marfiles siriofenicios. El autor encuentra una proximidad iconográfica entre "el guerrero" y las representaciones de guerreros de Karatepe por sus aspectos formales, pero remarca una mayor relación con el de Zincirli ${ }^{138}$ en lo que se refiere a la identificación del personaje. La existencia de representaciones de seres dobles, como las quimeras de Zincirli, Karkemish o Tell Halaf, le sirven de paralelo para el/los personaje(s) sentados en el trono. ${ }^{139}$

Algunas comparaciones en la misma dirección han hecho otros especialistas, así L. Abad y M. Bendala ${ }^{140}$ consideran que los leones siguen paralelos estrictos neohititas, siendo especialmente remarcables los que ofrecen los de Karkemish, del s. IX a.C. Los detalles anatómicos de las figuras humanas, sus vestiduras y calzados terminados en punta levantada o el gusto por los seres monstruosos les permiten también confirmar la procedente neohitita del estilo de los frisos. El aspecto janiforme del jabalí tendría analogías con los dos prótomos de león del llamado dios del puñal del santuario de Yacilikaya, obra del imperio nuevo hitita, s. XIII a.C. Por su parte M. Bendala apunta una relación con algún taller propiamente neohitita o bien con uno luvio-arameo ${ }^{141} \mathrm{H}$. Parzinger ${ }^{142}$ reconoce similitudes con las representaciones plásticas de los grandes vasos neohititas de Inandiktepe, así como con las de las sítulas y páteras orientalizantes halladas en Etruria y el ámbito alpino, esta última una relación que no vemos.

Si revisamos la relivaria neohitita podemos encontrar una mayor cercanía a los frisos de Milid (Malatya) y algo menor a los de Guzana (Tell Halaf). En los relieves de Milid, en el alto Eufrates, encontramos algunos elementos significativos: así el tocado que porta el rey FAUST en uno de ellos ${ }^{143}$ nos recuerda el del "guerrero" de P.M., así como el faldellín y el calzado apuntado del dios de la "Tormenta" en el mismo

\footnotetext{
135 Blánquez Pérez 1993, 121; Bendala Galán 1998, 109.

136 Almagro Gorbea 1983, 216.

137 Almagro Gorbea 1983, 217.

138 Orthmann 1971, 241.

139 Almagro Gorbea 1983, 264.

140 Abad Casal - Bengala Galán 1999, 69 y 72.

141 Bendala 1998, 109.

142 PARZINGer 1991.

143 Akurgal 1962, 105.
} 
relieve sirio. La harpé de la deidad nos remite a la misma arma que porta el personaje principal del friso del "dendróforo". ${ }^{144}$

En otro relieve del mismo lugar un dios con tiara de cuernos ataca a un gran dragón-serpiente, detrás se encuentra otra deidad con tiara de cuernos portando una lanza y una maza, ${ }^{145}$ quizás una escena similar se encontraba en la parte alta del monumento albacetense, a juzgar por el hallazgo de dos fragmentos de un imponente ser pisciforme. De allí, otro de la misma cronología y tradición nos muestra un diphros con las patas cruzadas y respaldo, semejante al del friso de la diosa alada. ${ }^{146}$

Es quizás el conjunto que aporta más elementos relacionados, iconográficamente hablando, con el monumento de P.M. También la considerable longitud en comparación con la altura de los frisos de Milid, mayor que en el resto de la relivaria neohitita, es una característica que detectamos en los frisos de P.M. Por su parte algunos frisos de Guzana (Tell Halaf), a pesar de mostrarnos una temática en absoluto diferente y la falta de elementos iconográficos equiparables, cuentan con un mayor "movimiento", que mostrarían una cierta analogía con las representaciones de P.M. frente a la generalizada rigidez de las imágenes neohititas. ${ }^{147}$

Pasando específicamente a los relieves que nos ocupan, la vestimenta larga con pliegues en la parte inferior del borde del "mayordomo/visir" que se encuentra delante de la deidad entronizada, la halla J. M. Blázquez ${ }^{148}$ en distintos personajes reales y dioses en relieves neohititas de Kizildad, de Malatya, Karkemish, Zincirli, Marash, de los siglos IX y VIII a.C. La apreciación es exacta, no sólo en lo que se refiere a los pliegues sino también en la indicación de la banda entre éstos y la falda, algo que no permanece en la relivaria siria inmediatamente posterior, ya de estilo asirizante.

Al mismo contexto cultural nos remite el lenguaje iconográfico que permite la representación de cabezas superpuestas que vemos en la deidad del trono, así no son infrecuentes las esfinges aladas con cabeza de león que tienen encima una cabeza humanizada de deidad con tiara de cuernos. ${ }^{149}$ El peinado y nariz picuda de los seres híbridos que sujetan los dos jabalíes unidos por el tronco del friso alto encuentran también el mismo trazo en varios relieves de la zona. ${ }^{150}$ Tampoco están ausentes las representaciones de seres janifrontes, normalmente de aspecto leonino, ${ }^{151}$ pero no hemos visto en ningún caso el verraco de P.M.

144 Estas representaciones parecen recoger la tradición del clasicismo hitita que se aprecia en los frisos del santuario de Yazilikaya, donde encontramos relieves con dioses con la harpé, faldellín picudo y calzado de punta (Neve 1985, relieves 1-39 y 69-80.). Debo a la Dra. Rosa Sanz Serrano poder consultar dicha publicación así como otras de difícil acceso sobre el mundo hitita.

145 ANET, 218 y 329.

146 VIEYRA 1955, abb. 65; GENGE 1979, II, VIII, abb. 42.

147 Véase a este respecto: Hombre sobre un dromedario; hombre subido a una escalera apoyada sobre una palmera esquematizada en palmeta; cáprido en movimiento delante de árbol (GENGE 1979, II, abb. 9, 10, 12).

148 BlÁzQuez Martínez 1992, 356.

149 Genge 1979, II, abb. 87, 89 y 90.

150 GenGe 1979, II, abb. 36, 87 y 95. El último de ellos representando un hombre o divinidad con cuerpo de pez.

151 Uno de cuyos precedentes puede estar en la efigie del llamado "dios puñal" con un león janifronte del santuario rupestre de Yacilikaya que NEve (1985, Relieve 82) considera correspondiente a la influencia mesopotámica. 
Estas representaciones de estilo neohitita se interrumpen en Milid (Malatya) bruscamente en el 808 a.C. ${ }^{152}$ En otros lugares, donde aparecen ciertos elementos concomitantes, éstos nos remiten también a una alta cronología: el dios de la tormenta de Alepo con inscripción luvita, calzado puntiagudo y faldellín con cinturón, se data en el s. IX a.C.; ${ }^{153}$ así como los ortostatos de dicho estilo de Sam'al (Zincirli). ${ }^{154} \mathrm{La}$ influencia neoasiria sobre la relivaria de tradición hitita marca una fecha ante quem para determinar en qué momento se fosiliza el influjo estilístico neohitita que se detecta en P.M., pues cambia el tipo de calzado, los vestidos y hasta el armamento, así como el tratamiento del cabello, y nada de ello aparece en la torre funeraria. Incluso la penetración del estilo asirio alcanza Anatolia, donde no pervive el estilo neohitita desde el último cuarto del siglo VIII a.C. ${ }^{155}$ En esa misma época sólo Karatepe, la localidad anatólica de las estribaciones del Tauro, parece retener aún en la segunda mitad del s. VIII a.C. algo de la tradición hitita del norte de Siria, aunque de forma muy apagada. Es interesante destacar que el constructor de la fortaleza de Karatepe dejó sendas inscripciones en jeroglífico luvita y en fenicio, lo cual muestra la extensión comercial fenicia que se había señalado para el reino de Alepo. ${ }^{156}$

En suma parece apuntarse, por lo que acabamos de ver, que la mayoría de los rasgos neohititas que vemos en P.M. aparecen con mayor profusión en Siria durante el s. IX a.C. siendo más difícil encontrarlos durante el s. VIII a.C. Es, pues, en ese marco cronológico cuando los artesanos de un taller áulico sirio se trasladaron a Tiro o al Extremo Occidente en el contexto de la importante ola colonizadora fenicia. A este respecto, creo que es relevante el vínculo establecido entre Tiro y el reino arameo de Arpad en el norte de Siria. Las primeras menciones al dios Melqart de Tiro, tanto epigráficas como iconográficas, no proceden de la metrópoli, sino precisamente de Arpad. ${ }^{157}$ Pero no se trata de la simple constatación de la introducción del culto de la divinidad para uso sólo de los comerciantes tirios, sino que se puede hablar de una importante integración de esta divinidad en el panteón local. A este respecto es elocuente que en el tratado establecido entre el rey de Arpad y Assurnirari V, rey de Asiria, fechado en el 754 a.C. aparezca Melqart en la segunda tríada garante del pacto, ${ }^{158}$ apenas veinte años antes de que este reino desapareciera y se convirtiera en provincia asiria. En otros ámbitos del norte del país y en Cilicia fue importante la presencia fenicia entre los siglos IX y VII a.C. señalándose una destacada concentración tiria precisamente en el reino con capital en Alepo. ${ }^{159}$

152 FrankFort 1954 [ed. Esp. 1982], 105.

153 LIPINSKI 2000, 635.

154 KLengel 1979, fig. 60 y 62.

155 Los fragmentos de esculturas de Kultepe muestran la nueva influencia durante dicho siglo igual que en Arslantepe, así como la aramea claramente en el último cuarto del siglo VIII a.C. (ÖzGÜÇ 1971, 124-125).

156 FrankForT 1954 [ed. Esp. 1982], 324.

157 La estela del rey Barhadad dedicada al dios, realizada en torno al 800 a.C., fue descubierta en el pueblo de Breg, con la primera atestación del teónimo y la única representación segura del dios gracias a la inscripción que se encuentra en su base (PUECH 1992). Según Lipinski, la estela monumental con una dedicatoria real permite pensar en un lugar santo de una factoría tiria (LIPINSKI 1995, 229).

158 LIPINSKI 1995, 230.

159 LeBRUN 1987. 
A esta relación de Tiro con los estados del norte de Siria debemos ligar el desplazamiento de talleres áulicos de alguno de estos pequeños reinos, ${ }^{160}$ lo cual permitió a la postre concebir un monumento de las características del de P.M. Habría que inscribir la marcha, quizás, en el contexto de la presión asiria ya en la primera mitad del s. VIII a.C., pues los estados arameos y neohititas desaparecen en torno al 732 a.C. por la acción directa del rey Tiglath-pileser III, aunque ya antes el estilo de los relieves empieza a notar la influencia de la potencia hegemónica. A continuación, Sargón se anexionó poco después del 717 a.C. los estados neohititas vasallos del sudeste de Anatolia, desarrollando incluso una campaña contra el rey Mita de Mushku (Midas de Frigia), llegando hasta Gaza y Chipre. ${ }^{161}$ A estas últimas campañas se asocian grandes deportaciones, y la reocupación del territorio con aportes poblacionales asirios. Difícilmente pudo quedar en estas zonas algo del estilo neohitita. ${ }^{162}$

A este respecto, ya en un primer momento, M. Almagro Gorbea ${ }^{163}$ sugirió que era lógico pensar que la idea del monumento, sus representaciones plásticas y su contenido mitológico, llegaron al mismo tiempo a Occidente, propuesta que ha reafirmado y desarrollado en sus trabajos posteriores. ${ }^{164}$ Por otra parte sitúa su aparición en el área sirio-fenicia en una fecha que debía ser anterior a la desaparición del arte neohitita de dicha región "pues no se explicaría de otra manera su presencia temprana en el Mediterráneo Occidental donde no se pudo llevar ni recrear lo que ya hubiera quedado fuera de uso en Oriente". ${ }^{165}$

Sin duda es incuestionable la existencia de un proceso de adaptación próximo temporalmente al referido estilo neohitita que tiene lugar en la propia Fenicia o ya en Occidente que permitió incorporar otros elementos iconográficos como la decoración sogueada y la meandriforme registradas en la fábrica albacetense, así como el propio tipo de monumento, etc., además de la mayor parte de la temática escenificada, a lo que hay que sumar la incorporación en un momento indeterminado el diferente tratamiento de las piernas, una oculta detrás de la otra cuando el personaje está sentado, que difiere sustancialmente de la constante neohitita de representar ambas piernas una encima de la primera. ${ }^{166}$ Ese período adaptativo "en otra parte" es el que se corresponde con la génesis del tema representado.

160 Las composiciones de los frisos de P.M. no desmerecen en nada a la mayoría de los trabajos realizados en el mundo neohitita y son francamente mejores que algunos de ellos.

161 SAPORETti 1990, 179; KLENGEL 1992, 222-226.

162 Ciertamente a estos convulsos momentos concretamente se pueden vincular algunos de los desplazamientos de artesanos levantinos documentados exhaustivamente entre otros por BURKERT (1992, 2325), pero su estilo difiere grosso modo del reflejado en P.M.

163 Almagro Gorbea 1978, 269.

164 Almagro Gorbea 1983, 263 y 274-275; ID. 1993-1994, 114.

165 Almagro Gorbea 1983, 274. Podría ser, sin embargo, objetable el deslizamiento cronológico propuesto hacia fines del s. VIII o inicios del VII a.C. para su transferencia al Extremo Occidente.

166 Véase el personaje sentado en el friso del "banquete" y la diosa alada. Debo a I. Prieto Vilas esta indicación. 


\section{Escatología fenicia entre indígenas}

La dimensión de este trabajo, ya relativamente amplio, impide detenernos en la cuestión cronológica de la elevación del monumento funerario albacetense y la amplia discusión que ha generado, baste recordar simplemente que el ajuar funerario hallado en la base del edificio, intrusivo o no, ha sido fechado con relativa precisión en torno al 490 a.C., ${ }^{167}$ lo cual muestra un decalage notable con respecto a sus modelos estilísticos, aunque fuera más antiguo como proponen por un lado J. M. Blázquez ${ }^{168}$ y por otro L. Abad y M. Bendala. ${ }^{169}$ No vamos a entrar tampoco, por las mismas razones, en la cuestión de la existencia o no de una intermediación tartésica orientalizante entre el precedente fenicio y la obra hallada en un contexto espacial de importantes hallazgos de escultura ibérica.

Simplemente quisiera apuntar brevemente la existencia de un fondo ideológico en el mundo indígena culturalmente semitizado que hiciera comprensible el discurso que se ofrecía a su vista en los dos frisos que hemos tratado, y no quedarnos con la cómoda idea de que para ellos se trataba de incomprensibles "monigotes" o "elementos de prestigio".

Un anillo giratorio hallado en el conjunto que constituye el tesoro de La Aliseda (Cáceres) presenta en el entalle una divinidad entronizada bicéfala que despliega cuatro alas, porta el ankh egipcio y tres flores de loto ocupan los campos vacíos. ${ }^{170} \mathrm{Ya}$ M. C. Marín Ceballos ${ }^{171}$ lo ha identificado con el dios El, siguiendo la descripción de la deidad reportada por Filón de Biblos ${ }^{172}$ y que hemos comentado unas páginas atrás. La conexión con la deidad entronizada en el friso de P.M. parece pues muy pertinente y contribuye a apuntar la comprensión de estas imágenes en el mundo orientalizante indígena, al menos en la esfera aristocrática.

El hallazgo pertenece a un conjunto homogéneo fechable entre fines del s. VII y mediados del VI a.C. ${ }^{173}$ en el que distintos objetos, la mayoría de ellos importados, ${ }^{174}$ cuentan con una elaborada iconografía cuyo significado, coherencia simbólica y especificidad sorprenden y muestran su vinculación con un discurso áulico. Ello se aprecia además de en el anillo comentado, en el tema del gran colgante en forma de sello giratorio, ${ }^{175}$ en el discurso fertilístico asociado a la realeza que aparece desta-

167 Almagro Gorbea 1983, 184-188; Olmos 1996, 100.

168 BLÁZQUEZ 1979, 155.

169 Abad Casal - Bendala Galán 1999, 62.

170 BlázQuez 1975, 132-133, lám. 46-47B; Almagro Gorbea 1977, 208-209, lám. XXIX.

171 En un trabajo que no he podido consultar: Cultos orientales en Tartessos, Abderramán, I, citado por BLÁZQUEZ 1992, 382.

172 Filo. P.E. I, 10, 36-37.

173 BLÁZQUEZ 1983, 126.

174 Aubet (1987) y Almagro Gorbea $(1989,277)$ creen que las joyas son obras de encargo a talleres, regalos políticos de los agentes comerciales fenicios a los aristócratas indígenas a cambio de productos locales.

175 Gran sello giratorio de La Aliseda (BlázQuez 1975, 131-132, fig. 36, lám. 45B; Almagro Gorbea 1977, 208, lám. XXVIII) con árbol de la vida flanqueado por dos grifos rampantes, sobre él vuela un ave (halcón), a ambos lados, dos deidades, la izquierda masculina barbada, la de la derecha, quizás femenina, ambas con el cetro en una mano mientras extienden la otra con la palma levantada. Escenas análogas se encuentran en el British Museum y en marfiles de Nimrud (BLÁzQuez 1999, 173). 
cado en los pendientes y brazaletes y la iconografía del cinturón con el dios/héroe luchando con un león junto a un árbol de la vida dominado por éste y los grifos que representan el caos.

Si aún no ha quedado claro, y quizás no lo quedará nunca, de si se trata del ajuar de una tumba con muros de mampostería o su pertenencia a un edificio de funcionalidad no identificada, ${ }^{176} \mathrm{y}$ se discute si era propiedad de una gran dama o una sacerdotisa, ${ }^{177}$ sin embargo, parece evidente que la riqueza del ajuar y su estricta simbología remiten más a una importante función religiosa de carácter regio/divino desempeñado por la dama que portaba dichas joyas que a unos simples adornos, regios eso sí, sin apenas significado. En dicho contexto cobra sentido el anillo giratorio con la efigie de la deidad de doble cabeza.

Referido al ritual regio del pgr cananeo y su pervivencia durante el primer milenio, G. del Olmo Lete ${ }^{178}$ había tenido en cuenta una noticia del profeta Ezequiel ${ }^{179}$ sobre la profanación del templo de Yahvé con prácticas referidas a las "prostituciones" y los cadáveres de los reyes.

Ambos elementos parecen estar muy presentes en el último edificio de Cancho Roano. Dicho complejo sacro (A) cuenta con un fuerte esquema palacial destacable incluso en el plano ideológico ${ }^{180}$ en el que se hallan numerosas pequeñas habitaciones perimetrales destinadas a la prostitución sagrada ${ }^{181}$ comparables a las del santuario de Pyrgi, ${ }^{182}$ donde el dinasta etrusco participa en un ritual hierogámico de tipo fenicio, plenamente integrado en una celebración de carácter ctónico.

La lectura de la línea 6 de la lámina fenicia de Pyrgi ${ }^{183}$ nos parece esclarecedora a este respecto. En ella se explica la razón de porqué el rey hace la donación de la tw (cámara?): "porque Astarté ha sido desposada (comprometida?) ${ }^{184}$ por su intermediación". Lo cual supone la celebración de una hierogamia entre la diosa (a través de una sustituta) y el rey como representante del dios, seguramente en dicho espacio sacro. ${ }^{185} \mathrm{La}$ ofrenda de la tw para el rito de hierogamia según la inscripción pyrgiense, realizada en el mes de $k r r$, tiene lugar exactamente el día del sepelio de una divinidad innominada en la que se ha visto mayoritariamente a Melqart, ${ }^{186}$ pero la ausencia del nombre permite sugerir que se trate del propio antecesor del monarca recién divini-

176 Dada la escasez de datos que pudo recabar J. R. Mélida respecto al hallazgo fortuito (véase por último TORRES 1999, 108).

177 BlÁzQuez 1983, 131, siguiendo a Nicolini.

178 Olmo Lete 1996, 84.

179 Ez. 43, 7-9.

180 Almagro Gorbea - Domínguez 1989.

181 BLÁzQUEZ 2000. Podemos añadir a los paralelos aportados por el profesor Blázquez otro especialmente llamativo: en dos de dichas habitaciones aparecieron restos de sendos telares, fenómeno que se repite en las habitaciones destinadas a la prostitución sagrada en el templo de Jerusalén en tiempos de Josías (640-609 a.C.) donde se tejían mantos a Ashera (II Reyes, 23, 4-7). El fenómeno se da también en una habitación del sector NW del edificio central, cuyo uso nosotros relacionamos con prácticas hierogámicas como veremos más adelante.

182 Celestino Pérez 1997, 379.

183 KAI 277.

184 GARBINI $(1989,181-183)$ prefiere traducir ' $r s ̌$ por compromiso en vez de desposorio.

185 Delcor 1974, 64.

186 Cf. Bonnet 1988, 289; ID. 1996, 121 y 122. 
zado, con lo que estaríamos ante un funus regio y a continuación el ritual relativo al acceso al trono del nuevo monarca. ${ }^{187}$

También la disposición del último edificio extremeño en forma de torre de escalones le permite a M. Torres ${ }^{188}$ recordar un texto ritual ugarítico relativo a las prácticas cultuales relacionadas con los antepasados dinásticos en "la torre" ( $m g d l)$ a donde "bajan" los difuntos reales. ${ }^{189}$ Así, como señala M. Torres: "existen en Cancho Roano A y B los elementos estructurales que permiten relacionar el edificio con un culto funerario con connotaciones regias de características claramente cananeas". ${ }^{190}$ Confirmaría también dicho significado la aparición de una "estela de guerrero" en la escalinata del santuario A de Cancho Roano, lo que permitiría sospechar que la amortización del monumento de un antepasado en dicho espacio sacro (concretamente en el acceso al edificio central) fue la última después de haberlo sido quizás en los santuarios anteriores. ${ }^{191}$ Dicho carácter ctónico referido a la dinastía gobernante se apreciaría también en los santuarios anteriores según concluye I. Prieto Vilas en su reciente estudio de la forma de "lingote chipriota" en el sur de la Península. ${ }^{192}$

Además de las dependencias perimetrales destinadas a la prostitución sagrada, llaman la atención en el último santuario de Cancho Roano los aposentos del sector NW del edificio central, los que Almagro Gorbea ${ }^{193}$ interpreta como habitaciones privadas y dormitorios de "cámara con alcoba" del dinasta, donde han aparecido elementos de tocador y joyas; elementos suntuarios, muebles y juegos de marfil, etc.; elementos de vestido: fíbulas, broches; elementos de banquete: copas, asadores; dos telares, "quizás de la esposa del dinasta", que interpreta como dedicación aristocrática de la señora del palacio. Nosotros pondríamos el énfasis en el uso de estas dependencias "domésticas" de uso regio en relación con ritos hierogámicos dada la función inequívoca de este edificio como santuario. ${ }^{194}$

Si volvemos de nuevo a los esclarecedores textos de Ugarit, nos encontramos que en $K T U 1.132$, donde se conserva el ritual de entronización del nuevo rey, un festival de 21 días, en el día décimonoveno se adereza el lecho de la diosa Pidrayu con motivo de la instalación del rey. Se trata de una hierogamia regia con la diosa, hija de Baal, diosa tutelar de la dinastía, considerada la novia divina por excelencia. ${ }^{195}$

El santuario de Cancho Roano parece, pues, el centro de un ritual regio de culto a los antepasados dinásticos donde se debía realizar sacrificios de tipo pgr relativos

187 También en Ugarit, reyes difuntos y divinizados, son mencionados con el determinativo divino (KTU, $1.113 ; 1.161 ; 1.22$; RIBICHINI 1981, 846).

188 Torres Ortiz 2002, 333.

189 KTU 112, 17-19.

190 Torres Ortiz 2002, 333.

191 No sucede así con la estela de Arroyo Manzanas, la otra estela encontrada en proceso de excavación, hallada en un espacio de habitación muy tardío, por lo que es más que probable la pérdida en este caso de cualquier recuerdo de su origen, aunque parezca probable su procedencia de un ámbito funerario (MORENO ARRASTIO 1995, 289).

192 Prieto Vilas 2002, 177.

193 Almagro Gorbea 1993, 141-142.

194 Los importantes trabajos realizados por S. Celestino no dejan ningún margen a la duda.

195 Así lo confirma KTU 1.24:26 (Olmo Lete 1992, 140). Además esta diosa es la que acompaña a su padre, Baal, en el descenso a la morada de Mot, con lo que se constata también su carácter ctónico. 
a la divinización de los monarcas extintos además de los regulares del culto a los ancestros. Ritos que se debían complementar con los hierogámicos propios del acceso del nuevo dinasta, repetidos estacionalmente con motivo del papel procurador de la fertilidad de la realeza, de alguna manera encarnando el papel de las deidades fertilísticas. El santuario de Cancho Roano tiene notables concomitancias con el de Jerusalén imaginado por Ezequiel y del que se rechaza la inclusión de la prostitución sagrada y los cadáveres de los reyes. Precisamente ambos tienen el pórtico orientado al Este desde donde llega el espíritu del dios y ambos son rodeados por el agua. ${ }^{196}$ Si recordamos el escenario de la residencia mítica de El "en la fuente de los ríos, en medio del curso de los dos océanos", ${ }^{197}$ parece evidente que el santuario extremeño con el estanque que rodea todo el complejo sacro, como el de Yahvé que concibe Ezequiel y el Maabet de Amrith, ${ }^{198}$ intenta reproducir a escala la morada mítica de El, su familia de dioses y los rephaim, la "torre de Kronos" a la que se dirigen en su viaje postrero los hombres perfectos. ${ }^{199}$

En las discusiones del Coloquio del C.E.F.Y.P. "Intercambio y comercio preclásico en el Mediterráneo" (Madrid, 1998), A. M. Arruda ya llamó la atención sobre la necesidad de valorar otras posibilidades funcionales para el edificio de Abul. Según la autora, la propia planta es una de las principales razones utilizadas para su definición como factoría, pero su similitud con la planta de Cancho Roano debería ser tenida en cuenta para otras lecturas funcionales del edificio del estuario del Sado, remarcando también el parecido entre ambos edificios en cuanto a dimensiones como ya ha visto S. Celestino. ${ }^{200}$ Abul es una construcción fenicia realizada ex novo en el s. VII a.C. ${ }^{201}$ entre dos grandes asentamientos indígenas, Setúbal y Alcacer Do Sal, y se localiza en la margen derecha del Sado, situado en una pequeña lengua de tierra separada de tierra firme por un foso. Se compone de un conjunto de habitaciones con un grueso muro exterior distribuidas en torno a un patio con un altar y domina todo el complejo precisamente una torre ${ }^{202}$ La existencia del altar en el centro del edificio permite valorar la función sacra del complejo, así como el hecho de que después de

\footnotetext{
196 M. Torres me ha llamado la atención sobre esta significativa relación.

197 KTU 1.23.

198 El Maabet de Amrit, un naiskos que debía albergar la imagen de la/s divinidad/es o sus betilos se encuentra en medio de un gran estanque (DunNAND - SALIBY 1985, pl. LXIII).

199 Pi. O. 2.70. Todo esto no hace más que abundar en la confirmación de la "Monarquía Sacra" defendida con infinidad de indicios en numerosas publicaciones por Martín Almagro Gorbea para el período Orientalizante y los comienzos del mundo ibérico.

200 Celestino PÉrez 1997.

201 El aspecto fenicio de la planta del edificio de Cancho Roano y la implicación de los semitas en su construcción ya los vimos hace años (López PARdo 1990). Pero el trabajo había sido publicado en mal momento, en medio de una arrolladora corriente reivindicativa de lo indígena que no dejaba ningún margen a la presencia de los fenicios en el interior de la Península, por ello no es de extrañar que se optara por extender un velo sobre dichas propuestas. No obstante, mi siempre apreciado maestro, el profesor Blázquez, con una regularidad inusitada a lo largo de doce años me ha recordado su adhesión a la propuesta lanzada sobre Cancho Roano. El descubrimiento de Abul parece poner de manifiesto lo acertado de dicha tesis.

202 A este respecto, me parece inevitable recordar el relativo parecido fonético con Abul, nombre actual del yacimiento fenicio de la desembocadura del Sado (Portugal), con el de migdol/mogdul (torre en feniciopúnico). Sobre este asunto, Carlos Tavares Da Silva ha tenido la amabilidad de señalarme que el origen del topónimo de Abul se pierde en el tiempo y que sin duda no es portugués sino semita.
} 
la amortización del mismo se construyera un lugar de culto al lado. ${ }^{203}$ Creemos que representa, pues, la búsqueda de un entorno acuático cuyo aislamiento se refuerza con un foso, el mismo escenario simbólico que se busca por obra hidráulica en Cancho Roano. La doctora Arruda se extraña también de que habiéndose constatado una presencia fenicia en el importante y próximo hábitat indígena de Setúbal ya en el s. VIII a.C. los fenicios tuvieran la necesidad de construir a cierta distancia un pequeño edificio factorial en el s. VII a.C. Ello no hace más que aportar argumentos a favor de la identificación del edificio como edificio sacro con las mismas connotaciones que el extremeño.

Unos elementos de bronce pertenecientes a un lecho, fechable en el s. VII ${ }^{204} \mathrm{o}$ en el s. VI a.C. ${ }^{205}$ fueron hallados en un edificio de planta semita de Torreón de Abajo (Cáceres), datado en el s. V a.C. ${ }^{206}$ La construcción está aislada junto al camino que llevaba del vado del Guadiana en Medellín al de Alconétar en el Tajo. Tal hallazgo en un edificio de carácter sacro unido a la existencia de una urna con los restos de un personaje cremado ha tenido difícil explicación: como un espacio sacro amortizado a continuación como tumba, con lo cual habría perdido el significado ideológico inicial. Convendría mejor indicar un papel extraordinariamente similar al de Cancho Roano, de hierogamia unida al culto a los antepasados. ${ }^{207}$

En suma distintos indicios apuntan a una notable implantación de las tradiciones cananeas en el mundo indígena peninsular en contacto más estrecho con los colonizadores semitas, pero no como simple asunción de un modelo monárquico y su liturgia que se conoce por el mero contacto con los fenicios, imposible de imitar pues los reyes quedaron en Oriente, sino dentro de una estrategia de la elite colonial que favorece la afirmación de estas monarquías mediante el ofrecimiento de una ideología con su correspondiente liturgia, la donación de muchos de los objetos necesarios para representarla, etc. Ello no podía ser más rentable para sus intereses comerciales a la vez que procuran la estabilidad de sistemas dinásticos tan necesarios para mantener un sistema de explotación y de intercambios permanentes. La fácil aceptación de dicho modelo, que los fenicios ensayaron en otros lugares del Mediterráneo, como Italia o el Norte de África, por parte de las elites indígenas tiene su lógica en su utilidad como afirmación de la realeza y de la permanencia de un grupo dinástico determinado. A nosotros no nos caben dudas, pues, de la capacidad de comprensión y la asimilación por parte de dinastas y aristocracia indígenas de la compleja teoría escatológica fenicia expresada en los dos frisos analizados.

203 MaYeT - SiLva 1997.

204 JiMÉNEZ Ávila 1998, 86, 92; ID. 2002, 255.

205 García-Hoz - Álvarez Rojas 1991, 203.

206 Jiménez Ávila 2002, 254. Remitimos a su minucioso estudio de este lecho para las cuestiones de funcionalidad general, cronología y estilo (ID. 2002, 245-259).

207 El santuario de la Alcudia también cuenta con elementos estructurales similares, al aparecer también un enterramiento en su interior (Moneo 1995, 248-249) y estar dominado por una torre. 


\section{Bibliografía}

Abad Casal, L. - Bendala Galán, M. (1999): El arte ibérico, Madrid.

Akurgal, E. (1962): The Art of the Hittites, London.

Almagro Gorbea, M.

(1977): El Bronce Final y el Período Orientalizante en Extremadura, Madrid.

(1978): "Los relieves mitológicos orientalizantes de Pozo Moro", TP 35, 251-278.

(1983): "Pozo Moro. El monumento orientalizante, su contexto socio-cultural y sus paralelos en la arquitectura funeraria ibérica", Madrider Mitteilungen 24, 177 293.

(1989): “Arqueología e Historia Antigua: el proceso protoorientalizante y el inicio de los contactos de Tartessos con el Levante mediterráneo", Anejos de Gerión 2, 277-288.

(1993): "Tarteso desde sus áreas de influencia: la sociedad palacial en la Península Ibérica”, [en] J. Alvar y J. M. Blázquez (eds.), Los enigmas de Tarteso, Madrid, 139-161.

(1993-1994): "Ritos y cultos funerarios en el Mundo Ibérico", Anales de Prehistoria y Arqueología 9-10, 107-133.

Almagro Gorbea, M. - Domínguez de la Concha, A. (1988-1989): “El palacio de Cancho Roano y sus paralelos arquitectónicos y funcionales", Zephyrus 41-42, 339-382.

ANET = J. B. PRITCHARD (ed.), Ancient Near Eastern Texts Relating to the Old Testament, Third Edition with Supplement, Princeton, 1969.

ANET, Supl. = J. B. PritchARD (ed.), The Ancient Near Eastern. Supplementary Texts and Pictures Relating to the Old Testament, Princeton, 1969.

Aubet, M. E. (1987): Tiro y las colonias fenicias de Occidente, Barcelona.

Baumgarten, A. I. (1981): The Phoenician History of Philo of Byblos, Leiden.

Bendala Galán, M. (1998): "Los Íberos conquistan Europa”, Historia 16 263, 100111.

Black, J. - Green, A. (1992): Gods, Demons and Symbols of Ancient Mesopotamia. An Illustrated Dictionary, Avon.

BláNQuez PÉrez, J. J.

(1993): "El mundo funerario albacetense y el problema de la escultura ibérica: la necrópolis de Los Villares", [en] J. Blánquez - R. Sanz - M. T. Musat (eds.) Arqueología en Albacete, Albacete, 111-128.

(1999): "El tratamiento informático y los vestigios ibéricos. Algunos ejemplos", [en] J. Blánquez - L. Roldán (eds.), La cultura Ibérica a través de las fotografias de principios de siglo. Un homenaje a la memoria, Madrid, 265-270.

BlázQuez Martínez, J. M.

(1975): Tartessos y los orígenes de la colonización fenicia en Occidente, Salamanca.

(1979): "Las raíces clásicas de la cultura ibérica", AEspA 52, 141-171.

(1983): “Gerión y otros mitos griegos en Occidente", Gerión 1, 21-38. 
(1992): Fenicios, griegos y cartagineses en Occidente, Madrid.

(1998-1999): "Temas religiosos en la pintura vascular tartésica e ibérica y sus prototipos del Próximo Oriente fenicio", Lucentum 18, 93-116.

(1999): "El impacto de la religión semita, fenicios y cartagineses en la religión íbera", [en] Religión y magia en la Antigüedad, Valencia, 49-87.

(2000): "El santuario de Cancho Roano (Badajoz), la prostitución sagrada", [en] Homenaje G. Del Olmo Lete, Aula Orientalis 17-18, 367-379.

(2001): "Algunos mitos y ritos orientales traídos por los fenicios a Occidente", [en] De la Estepa al Mediterráneo, Actas del Ier Congreso de Arqueología e Historia Antigua del Oriente Próximo, Barcelona, 205-226.

BLECH, M. (1997): "Los inicios de la iconografía de la escultura ibérica en piedra: Pozo Moro", [en] Iconografia ibérica, iconografia itálica: propuestas de interpretación y lectura, Madrid, 193-210.

BONNET, C.

(1985): "Melqart, Bès et l'Héraclès Dactyle de Crète", [en] E. Gubel - E. Lipinski (eds.), Phoenicia and Its Neighbours, Leuven, 231-240.

(1987): "Typhon et Baal Saphon", [en] E. Lipinski (ed.), Phoenicia and the East Mediterranean in the First Millenium B.C., Leuven, 101-144.

(1988): Melqart. Cultes et mythes de l'Héraclès tyrien en Méditerranée, Leuven.

(1996): Astarté. Dossier documentaire et perspectives historiques, Roma.

Bonnet, C. - Xella, P. (1995): "La Religion", [en] V. Krings (ed.), La civilisation phénicienne et punique, Brill, 316-333.

Bordreuil, P. (1986): "Attestations inédites de Melqart, Baal Hamon et Baal Saphon à Tyr”, [en] C. Bonnet - E. Lipinski - P. Marchetti (eds.), Religio Phoenicia, Leuven, 77-86.

Bottéro, J. (1985): Mythes et rites de Babylone, Genève-Paris.

Bottéro, J. - Kramer, S. N. (1989): Lorsque les dieux faisaient l'homme. Mythologie Mésopotamienne, Paris.

Bron, F. (1979): Recherches sur les inscriptions phéniciennes de Karatepe, Paris.

Brown, S. (1991): Late Carthaginian Child Sacrifice and Sacrificial Monuments in their Mediterranean Context, Sheffield.

BURKERT, W.

(1992): The Orientalizing Revolution. Near Eastern Influence on Greek Culture in the Early Archaic Age, Cambridge.

(1999): Da Omero ai Magi, Venecia.

CAMPS, G.

(1954): "L'inscription de Béja et le problème des Dii Mauri", RAfr 98, 235-260.

(1995): “D 48. Dieux Africains et Dii Mauri”, Encyclopédie Berbère XV, 23212340 . 
CAquot, A - Sznyner, M. (1980): Ugaritic Religion, Leiden.

Caquot, A. - Sznycer, M. - Herdner, A. (1974): Textes Ougaritiques. Tome I. Mythes et legendes, Paris.

Castelo Ruano, R.

(1994): "Monumentos funerarios ibéricos: interpretación de algunos de los restos arquitectónicos y escultóricos aparecidos en las necrópolis del sureste peninsular", Revista de Estudios Ibéricos 1, 139-171.

(1995): Monumentos funerarios del sureste peninsular: elementos y técnicas constructivas, Madrid.

Celestino Pérez, S. (1997): "Santuarios, centros comerciales y paisajes sacros", Quaderns de Prehistòria y Arqueología de Castelló 18, 359-389.

CIS $=$ Corpus Inscriptionum Semiticarum, Paris, 1881.

Chuvin, P. - Yoyotte, J. (1986): "Documents relatifs au culte pélusien de Zeus Casios", R. Arch. 1, 41-63.

De Moor, J. C. (1971): The Seasonal Pattern in the Ugaritic Myth of Ba'lu According to the Version of Ilumiku (=Alter Orient un Altes Testament 16), Kevelaer/ Neukischen-Vluyn.

Delcor, M. (1974): "Le hieros gamos d'Astarte”, RSF 2, 63-76.

Desanges, J.

(1978): Recherches sur l'activité des méditerranéens aux confins de l'Afrique. (VIe siècle avant J.-C. -IVe siècle après J.-C.), Roma.

(1983): "Des interprètes chez les «Gorilles». Reflexions sur un artifice dans le «Periple d'Hannon»", [en] I Congresso di Studi Fenici e Punici. Roma, Nov. 1979, Roma, 267-270.

Destrooper-Georgiades, A. (1995): “La numismatique partim Orient”, [en] V. Krings (ed.), La civilisation phénicienne et punique, Leiden-New York, 148-165.

Dressler, H. H. P. (1976): The AQHT-Text: A New Transcription, translation, Commentary, and Introduction, Cambridge.

DrIVER, G. R. (1956): Canaanite Myths and Legends, Edinburgh.

Du Mesnil Du Buisson, R. (1973): Nouvelles études sur les dieux et les mythes de Canaan, Leiden.

Dunnad, M. - Saliby, N. (1985): Le temple d'Amrith dans la perée d'Aradus, Paris.

E.B.: "D52. Dioscures (Castores)", [en] Encyclopédie Berbère, 1995, XV, 2349-2352.

FANTAR, M. (1970): Eschatologie phénicienne-punique, Tunis.

Fernández Rodríguez, J. M. (1996): "Mitos y ritos de paso en la iconografía ibérica del poder: los relieves de Pozo Moro (Albacete)", Tabona 9, 297-316.

Frankfort, H. (1954): The Art and Architecture of the Ancient Orient, London [ed. Esp. 1982].

GarbinI, G. (1989): “L’iscrizione di Pyrgi”, RSF 17, 179-187. 
García-Hoz, Ma C. - Álvarez Rojas, A. (1991): "El Torrejón de Abajo. Cáceres”, Extremadura Arqueológica 2, 199-209.

Genge, H. (1979): Nordsyrisch-südanatolische Reliefs, København.

Gibson, J. C. L. (1978): Canaanite Myths and Legends, Edinburgh.

Ginsberg, H. L. (1969): "Ugaritic Myths, Epics, and Legends", [en] J. B. Pritchard (ed.), Ancient Near Eastern Texts Relating to the Old Testament, Third Edition with Supplement, Princeton, 129-155.

Goetze, A. (1969): "Hittite Myths, Epics, and Legends", [en] J. B. Pritchard (ed.), Ancient Near Eastern Texts Relating to the Old Testament, Third Edition with Supplement, Princeton, 519.

Grass, M. - Rouillard, P. - Teixidor, J. (1991): El universo fenicio, Madrid.

HaAs, V. (1982): Hethitische Berggötter und hurritische Steindämonen, Mainz am Rhein.

Haoftizzer, J. - Jongeling, K. (1995): Dictionary of the North-West Semitic Inscriptions, Leiden.

Healey, J. F. (1977): “The Underworld Character of the God Dagan”, JNSL 5, 43-51.

HeIDER, G. C. (1985): The Cult of Molek. A Reassessment, Sheffield.

Hermary, A. (1992): "Dioscures", [en] Dictionaire de la Civilisation Phéniciene et Punique, Paris, 131.

James, E. O. (1960): The Ancient Gods, London.

JiMÉNEZ ÁVILA, J.

(1998): "El lecho funerario orientalizante de «El Torrejón de Abajo» (Cáceres)", Madrider Mitteilungen 38, 67-98.

(2002): La toréutica orientalizante en la Península Ibérica, Madrid.

Jiménez Zamudio, R. (1998): El Poema de Erra, Estudio y traducción del texto original acadio, Madrid.

$K A I=\mathrm{H}$. DONNER - W. RöLlig, Kanaanäische und aramäische Inschriften, 19661969, Wiesbaden.

KLENGEL, H.

(1979): Geschichte un Kultur Altsyriens, Leipzig.

(1992): Syria, 3000 to 300 B.C., Berlin.

Krahmalkov, Ch. R. (2000): Phoenician-Punic Dictionary, Leuven.

$K T U=$ M. Dietrich - O. Loretz - J. Sanmartín (eds.), The Cuneiform Alphabetic Texts from Ugarit, Ras Ibn Hani and Others Places, Münster, 1995.

Lara Peinado, F. (2002): Leyendas de la antigua Mesopotamia. Dioses, héroes y seres fantásticos, Madrid.

Lebrun, R. (1987): "L'Anatolie et le monde phénicien du Xe au IV siècle av. J.-C.", [en] E. Lipinski (ed.), Phoenicia and the East Mediterranean in the First Millenium B.C., Leuven, 23-33. 
Levi della Vita, G. - Amadasi Guzzo, M. G. (1987): Iscrizioni puniche della Tripolitania (1927-1967), Roma.

LIPINSKI, E.

(1971): "El's Abobe, Mythological Traditions Related to Mount Hermon and the Mountains of Armenia", Orientalia Lovaniensia Periodica 2, 13-69.

(1995): Dieux et déesses de l'univers phénicien et punique, Leuven.

(2000): The Aramaeans. Their Ancient History, Culture, Religion, Leuven.

(2001): "Gorillas", Orientalia Lovaniensia Analecta 104, 79-85.

Liverani, M. (1995): El Antiguo Oriente. Historia, sociedad y economía, Barcelona.

López Pardo, F. (1990): "Sobre la función del edificio singular de Cancho Roano (Zalamea de la Serena, Badajoz)", Gerión 8, 141-162.

MAass-Lindemann, G. - MAAss, M. (1997): "Cintas-amuleto de láminas egiptizantes, procedentes de Andalucía", Boletín de la Real Academia de la Historia 194, 269296.

Madrigal Belinchón, A. (1995): "El monumento funerario ibérico de Pozo Moro", [en] A. García - C. Padilla (eds.), Creencias y ritos funerarios. Serie Guías didácticas del M.A.N. 1, Madrid, 14-15.

Marín Ceballos, M ${ }^{a}$ C. (1999): "Los dioses de la Cartago púnica", Treballs del Museu Arqueològic d'Eivissa i Formentera 43, 63-90.

MaYet, F. - Silva, C. T. (1997): "L'établissement phénicien d'Abul (Alcácer do Sal)”, [en] Itineraires Lusitaniens, Paris, 255-271.

Mazard, J. (1955): Corpus numorum Numidiae Mauretaniaeque, Paris.

Moneo, M ${ }^{a}$ T. (1995): "Santuarios urbanos en el mundo ibérico", Complutum 6, 245255.

Moran, W. L. (1969): “Akkadian Letters", [en] J. B. Pritchard (ed.), Ancient Near Eastern Texts Relating to the Old Testament, Third Edition with Supplement, Princeton, 623-632.

Moreno Arrastio, F. (1995): "La estela de Arroyo Manzanas (Las Herencias II, Toledo)", Gerión 13, 275-294.

Neve, P. (1985): Yazilikaya, Hatuscha Information, Berlín.

Olmo Lete, G. DEL

(1981): Mitos y leyendas de Canaán según la tradición de Ugarit, Valencia.

(1992): La religión cananea según la liturgia de Ugarit. Estudio textual, Barcelona.

(1996): El continuum cultural cananeo. Pervivencias cananeas en el mundo fenicio-púnico, Barcelona.

(1998): Mitos, leyendas y rituales de los semitas occidentales, Madrid.

Olmos Romera, R. (1996): "Pozo Moro: ensayos de lectura de un programa escultórico en el temprano mundo ibérico", [en] R. Olmos Romera (ed.), Al otro lado del espejo: aproximaciones a la imagen ibérica, Madrid, 99-114.

Orthmann, W. (1971): Untersuchungen zur Späthethitichen Kunst, Bonn. 
ÖzGüç, T. (1971): Kültepe and Its Vicinity in the Iron Age, Ankara.

PardeE, D. (1988): “Takamouna wa Šunama”, Ugarit-Forschungen 20, 195-199.

PARZINGer, H. (1991): “Inandiktepe - Este - Pozo Moro”, Bericht der Römisch-Germanischen Kommission 72, 5-44.

Pecchioli Daddi, D. - Polvani, A. M. (1990): La mitologia ittita, Brescia.

Podella, TH. (1991): "El más allá en las concepciones veterotestamentarias", [en] P. Xella (ed.), Arqueología del infierno: el más allá en el mundo antiguo PróximoOriental y Clásico, Sabadell, 139-160.

Prieto Vilas, I. (2002): “¿Apropiación o peervivencia?: el empleo de la simbología orientalizante en el Ibérico Antiguo", [en] S. Crespo Ortiz de Zárate - A. Alonso Ávila (eds.), Scripta Antiqua in honorem Ángel Montenegro Duque et José María Blázquez Martínez, Valladolid, 169-182.

Puech, E. M. (1992): "La stèle de Bar-Hadad à Melqart et les rois d'Arpad", Revue Biblique 99, 311-334.

Quillard, B. (1971-1972): "Les étuis porte-amulettes carthaginois", Karthago 17, $1-32$.

RIBICHINI, S.

(1981): Adonis. Aspetti “orientali" di un mito greco, Roma.

(1991): "Concepciones de la Ultratumba en el mundo fenicio y púnico", [en] P. Xella (ed.), Arqueología del infierno: el más allá en el mundo antiguo PróximoOriental y Clásico, Sabadell, 125-137.

(1994): "Le origini della città santa. Biblo nei miti della tradizione clásica", [en] Biblo. Una città e la sua cultura, Roma, 215-230.

(1996): "Su alcuni aspetti del Kronos fenicio", [en] E. Acquaro (ed.), Alle soglie della classicità il Mediterraneo tra tradizione e innovazione. Studi in onore di Sabatino Moscati, Pisa-Roma, 371-381.

Ruiz CABrero, L. A. (2003): "El estuche con banda mágica de Moraleda de Zafayona (Granada): una nueva inscripción fenicia", Byrsa 1, 85-106.

Sanmartín, J. (1999): "Génesis oriental de los dioses fenicios de las colonias occidentales", Treballs del Museu Arqueologic d'Eivissa i Formentera 43, 9-23.

SAPORETTI, CL. (1990): “Appendice I. testimonianze neo-assire relative alla Fenicia da Tiglat-Pileser III ad Assurbanipal”, [en] M. Botto, Studi storici sulla Fenicia l'VIII e il VII secolo a.C., Pisa, 109-243.

Scandone Matthiae, G. (1991): "El Más Allá en el antiguo Egipto", [en] P. Xella (ed.), Arqueología del infierno: el más allá en el mundo antiguo Próximo-Oriental y Clásico, Sabadell.

tha $=$ J. Mangas Manjarrés - D. Plácido Suárez (eds.), Testimonia Hispaniae Antiqua IIA, La Península Ibérica en los autores griegos: de Homero a Platón, Madrid, 1998. 
TORRES ORTIZ, M.

(1999): Sociedad y mundo funerario en Tartessos, Madrid.

(2002): Tartessos, Madrid.

Tsirkin, Y. B. (1991): “Japheth Progeny and the Phoenicians”, Orientalia Lovaniensia Analecta 44, 117-134.

VerCOUtTeR, J. (1945): Les objets égyptiennes et égyptisants du mobilier funéraire carthaginois, Paris.

VIAN, F. (1960): "Le mythe de Typhée et le problème de ses origines orientales", [en] Eléments orientaux dans la religion grecque ancienne, Paris, 27-37.

VIEYRA, M. (1955): Hittite Art 2300-750 B.C., London.

Virolleaud, Ch. (1941): "Les Réphaïm. Fragments de poèmes de Ras Shamra", Syria 22, 1-30.

XeLLA, P.

(1981): I testi rituali di Ugarit, I. Testi, Roma.

(1984): La terra di Baal, Roma. 